\title{
Influence of Carrier Structure and Physicochemical Factors on Immobilisation of Fungal Laccase in Terms of Bisphenol A Removal
}

\author{
Kamila Wlizło ${ }^{1,2, *}$, Jolanta Polak ${ }^{2, *} \mathbb{C D}$, Justyna Kapral-Piotrowska ${ }^{3}$, Marcin Grąz $^{2}$, \\ Roman Paduch ${ }^{4}\left(\mathbb{D}\right.$ and Anna Jarosz-Wilkołazka ${ }^{2}$ (D) \\ 1 Department of Industrial and Environmental Microbiology, Institute of Biological Sciences, \\ Maria Curie-Skłodowska University, Akademicka 19, 20-033 Lublin, Poland \\ 2 Department of Biochemistry and Biotechnology, Institute of Biological Sciences, Maria Curie-Skłodowska \\ University, Akademicka 19, 20-033 Lublin, Poland; graz@poczta.umcs.lublin.pl (M.G.); \\ anna.wilkolazka@poczta.umcs.lublin.pl (A.J.-W.) \\ 3 Department of Functional Anatomy and Cytobiology, Institute of Biological Sciences, \\ Maria Curie-Skłodowska University, Akademicka 19, 20-033 Lublin, Poland; \\ justyna.kapral-piotrowska@poczta.umcs.lublin.pl \\ 4 Department of Virology and Immunology, Institute of Biological Sciences, Maria Curie-Skłodowska \\ University, Akademicka 19, 20-033 Lublin, Poland; rpaduch@poczta.umcs.lublin.pl \\ * Correspondence: kamila.wlizlo@poczta.umcs.lublin.pl (K.W.); jpolak@poczta.umcs.lublin.pl (J.P.); \\ Tel.: +48-815-375-958 (K.W.); +48-815-375-051 (J.P.)
}

Received: 22 July 2020; Accepted: 17 August 2020; Published: 20 August 2020

\begin{abstract}
Laccase from Pleurotus ostreatus was immobilised on porous Purolite ${ }^{\circledR}$ carriers and amino-functionalised ultrafiltration membranes. The results indicated a correlation between the carrier structure and the activity of laccase immobilised thereon. The highest activity was obtained for carriers characterised by a small particle size and a larger pore diameter (the porous carriers with an additional spacer $\left(\mathrm{C}_{2}\right.$ and $\left.\mathrm{C}_{6}\right)$ and octadecyl methacrylate beads with immobilised laccase activity of $5.34 \mathrm{U} / \mathrm{g}, 2.12 \mathrm{U} / \mathrm{g}$ and $7.43 \mathrm{U} / \mathrm{g}$, respectively. The conditions of immobilisation and storage of immobilised laccase were modified to improve laccase activity in terms of bisphenol A transformation. The highest laccase immobilisation activity was obtained on small bead carriers with a large diameter of pores incubated in $0.1 \mathrm{M}$ phosphate buffer $\mathrm{pH} 7$ and for immobilisation time of $3 \mathrm{~h}$ at $22{ }^{\circ} \mathrm{C}$. The immobilised LAC was stable for four weeks maintaining $80-90 \%$ of its initial activity in the case of the best $C_{2}, C_{6}$, and $C_{18}$ carriers. The immobilised laccase transformed $10 \mathrm{mg} / \mathrm{L}$ of BPA in $45 \%$ efficiency and decreased its toxicity 3-fold in the Microtox tests. The effectiveness of BPA transformation, and the legitimacy of conducting this process due to the reduction of the toxicity of the resulting reaction products have been demonstrated. Reusability of immobilised LAC has been proven during BPA removal in 10 subsequent batches.
\end{abstract}

Keywords: laccase; immobilisation; porous carriers; membranes; bisphenol A; environmental toxicity

\section{Introduction}

Laccases are well-known biocatalysts for industrial purposes. Given their substrate promiscuity and the mild reaction conditions, this group of enzymes is widely studied in terms of green catalysis and especially improvement of their properties, which allows adaptation of laccases to specific biotechnological process conditions. Among modern approaches such as direct evolution and rational design, immobilisation of enzymes contributes to increasing laccase stability in adverse reaction conditions, such as extreme $\mathrm{pH}$ and temperature values or the presence of organic solvents [1]. 
Application of an immobilised enzyme in biocatalysis simplifies its separation from the reaction product and reuse in the continuous system of the biotechnological process. This reduces both the cost of production of the biocatalyst and the process itself; hence, immobilisation is the most promising method for industrial application of laccase and enzymes in general [2-4]. Many techniques and carriers for immobilisation have been developed over the years; however, there is no universal method of immobilisation or an ideal support for all enzymes and applications. Both have advantages and disadvantages, which need to be balanced through the optimisation process. Regarding immobilisation techniques, the choice is between the activity and stability of laccase, whereas the dilemma for the support lies between the limitations of substrate diffusion and the amount of laccase loaded on the support [5]. Therefore, the improvement of the immobilisation method in terms of the conditions of laccase attachment and extension of preparation's shelf life is still desired as well as searching for new, cheap supports. An interesting group of supports among many materials used for immobilisation, such as carbon and silica nanostructures, are acrylic resins due to their broad range of structural diversity and ease of modification [6,7]. Depending on the structure, they can be applied as supports for laccase immobilisation through covalent bonds and adsorption giving an efficient and repeatedly used biocatalyst [8]. An alternative for porous carriers may be ultrafiltration membranes characterised by low porosity, which are used especially for covalent attachment of laccase with simultaneous low substrate adsorption. Promising results were reported for laccase encapsulated in alginate, as high activity of immobilised laccase and simultaneous low substrate adsorption were noted $[9,10]$. However, there may be possible leaking of physically immobilised enzyme from the carrier and limited mass transfer, which are unfavourable phenomena $[5,10]$.

Several groups of porous acrylic carriers (Purolite ${ }^{\circledR}$ ) and amine-activated ultrafiltration membranes were tested as potential supports for immobilisation of fungal laccase from Pleurotus ostreatus. The supports differed in terms of the material they were made of, porosity, and immobilisation technique. The goals of this study were to carry out (1) evaluation of the correlation between the structure of the styrene and methacrylate carriers with the porosity ranged from 300 to $1800 \AA$ as well as cellulosic and polyethersulfonic membranes and the activity of immobilised laccase, (2) analysis of the impact of the physicochemical factors of the immobilisation process and storage conditions on the activity of immobilised laccase and long-term stability, (3) transformation of bisphenol A (BPA) as a model endocrine chemical compound and analysis of the process efficiency, and (4) evaluation of the process legitimacy based on the results of BPA transformation and the toxicity of its transformation products.

\section{Results and Discussion}

\subsection{Influence of the Carrier Structure}

The carrier structure and immobilisation technique are major factors limiting the process of enzyme bonding to the carriers and, consequently, the applicability of immobilised biocatalysts. The 18 tested supports represented two different groups, i.e., porous carriers and membranes. The former group included ready-to-use (1) supports dedicated for covalent immobilisation and possessing a short $\left(C_{2}\right)$ or long $\left(C_{6}\right)$ spacer arm, (2) supports used for adsorption and possessing octadecyl groups $\left(C_{18}\right)$, and (3) supports used for adsorption without any functional groups $\left(\mathrm{S}_{0}\right)$ (Figure 1).

The latter group comprised polyethersulfone (PES) and cellulose (CEL) membranes as potential supports for covalent immobilisation, which were additionally functionalised through silanisation. The scheme of LAC immobilisation on various types of carriers through covalent bonds and hydrophobic interactions is summarized in Figure 2. 


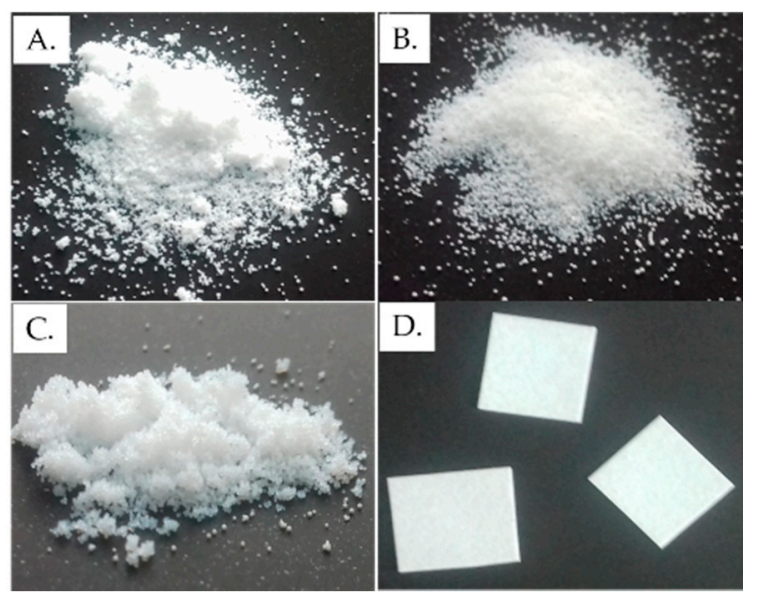

Figure 1. Pictures of carrier's beads and membranes used in BPA transformation; (A) C2C carrier, (B) C6C carrier, (C) C18C carrier, (D) CEL100 membrane.

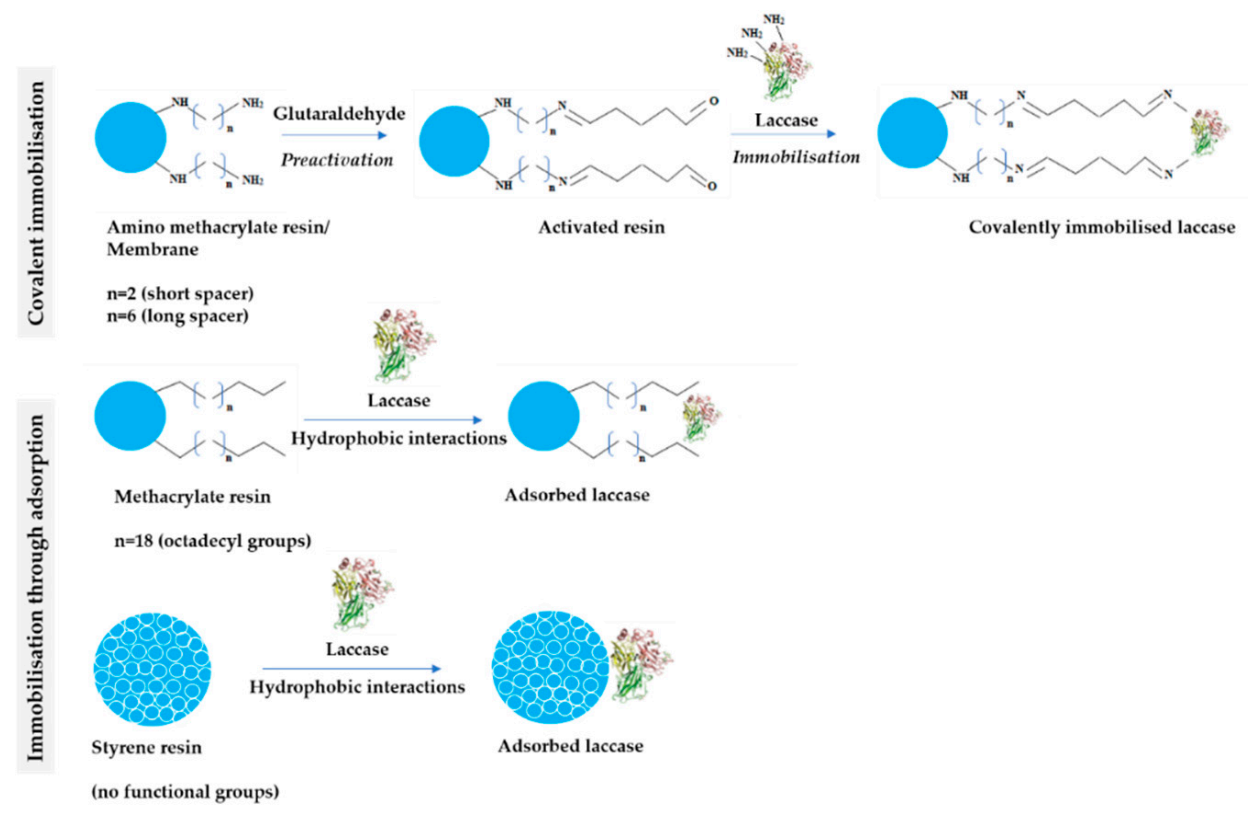

Figure 2. Schematic structure of tested carriers and the mechanism of laccase immobilisation covalently and through adsorption.

The present study showed a high impact of the carrier structure on the activity of immobilised laccase (LAC) from the Pleurotus ostreatus strain (Table 1). Both the LAC activity and the yield of protein bonded on porous carriers were significantly higher than in the case of membranes (PES and CEL). This was probably caused by the poor porosity and smaller surface area of the membranes, resulting in low protein loading confirmed by the Bradford method.

As described in several papers, acrylic beads with high porosity provided $100 \%$ of protein loading; hence, supports with high porosity are recommended for immobilisation of enzymes [11]. The highest LAC activity in the case of porous carriers with an additional $C_{2}$ and $C_{6}$ spacer and octadecyl methacrylate beads $\left(\mathrm{C}_{18}\right)$ was obtained for those characterised by a small particle size and a larger pore diameter (acronyms ending in a letter $\mathrm{C}$ ), i.e., a structure representing an optimal setup of carrier capacity and flow properties [11]. Interestingly, in the case of the $C_{2}$ and $C_{6}$ carriers, the decrease in the pore diameter reduced the immobilised LAC activity $(\mathrm{C} 2 \mathrm{~B}, \mathrm{C} 6 \mathrm{~B})$.

This may be the result of laccase immobilisation mainly on the carrier's surface. Therefore, LAC is not protected from external factors, which can be observed in the case of high porosity carriers [11]. 
Moreover, substrate and product dispersion can be limited due to the smaller pore size; hence, the detected activity of laccase is underestimated.

Table 1. Influence of the type of carrier and immobilisation technique on the activity of immobilised LAC from Pleurotus ostreatus [U/g] and yield of protein immobilisation [\%]—screening test.

\begin{tabular}{cccc}
\hline Immobilisation Technique & Carrier & $\begin{array}{c}\mathbf{A}_{\mathbf{i m m}} \\
{[\mathbf{U} / \mathbf{g}]}\end{array}$ & $\begin{array}{c}\text { Yield } \\
{[\%]}\end{array}$ \\
\hline \multirow{5}{*}{ Covalent } & C2A & $2.47 \pm 0.1$ & $40.5 \pm 5.4$ \\
& C2B & $1.58 \pm 0.3$ & $51 \pm 1$ \\
& C2C & $5.34 \pm 0.4$ & $80.5 \pm 2.5$ \\
& C2D & $1.86 \pm 0.1$ & $55.5 \pm 5.5$ \\
& C6A & $2.75 \pm 0.2$ & $76 \pm 3.6$ \\
& C6B & $2.12 \pm 0$ & $62 \pm 2.1$ \\
& C6C & $2.12 \pm 0.3$ & $68 \pm 0.1$ \\
& C6D & $2.65 \pm 0.2$ & $92 \pm 0.5$ \\
& CEL10 & $0.30 \pm 0$ & $1.23 \pm 0.1$ \\
& CEL100 & $0.33 \pm 0$ & $1.54 \pm 0.1$ \\
& PES10 & $0.55 \pm 0$ & $1.0 \pm 0.5$ \\
& PES100 & $0.88 \pm 0$ & $1.15 \pm 0$ \\
\hline Adsorption & C18A & $1.04 \pm 0.1$ & $100 \pm 0$ \\
& C18C & $7.43 \pm 0.3$ & $100 \pm 0.1$ \\
& C18D & $2.55 \pm 0.2$ & $100 \pm 0.1$ \\
& S0A & $5.80 \pm 0.9$ & $96 \pm 0.4$ \\
& S0B & $1.05 \pm 0.1$ & $85 \pm 3.5$ \\
& S0D & $3.87 \pm 0.3$ & $97 \pm 2.1$ \\
\hline
\end{tabular}

The length of the spacer arm had an imperceptible impact on the immobilisation process. This conclusion contradicts the general information that an optimal carrier should have a small spacer [5]. Indeed, a short spacer arm promotes multipoint laccase binding, thereby preventing its desorption, but may hinder the mobility of the bound enzyme molecules in contrast to those bound on the longer spacer arm $[12,13]$. Such bonding and stiffening of the LAC structure may be more desirable in terms of its long-term stability rather than activity.

The immobilisation of LAC was also possible on the tested membranes; however, the activity obtained was much lower than on the porous carriers. Nevertheless, there was a correlation between the pore diameter and the activity. Higher values were obtained after the immobilisation on membranes with $100 \mathrm{kDa}$ porosity, compared to $10 \mathrm{kDa}$, and the highest LAC activity was observed on the $100 \mathrm{kDa}$ cellulose membranes (CEL100).

Considering the immobilisation technique used, the highest activity of LAC was obtained via adsorption on the $\mathrm{C} 18 \mathrm{C}$ support, with a concomitant $100 \%$ protein bonding yield, whereas the lowest activity of LAC was detected for the covalent attachment of LAC to the PES membranes. The yields of protein bonding (covalently) to the $\mathrm{C}_{2}$ and $\mathrm{C}_{6}$ carriers were in the range from $40 \%$ to $92 \%$, whereas a $100 \%$ yield was noted in the case of the $C_{18}$ and $S_{0}$ supports (adsorption). This phenomenon was associated with the actual activity of immobilised LAC; however, the enzyme-carrier interactions were important. The cause of the lower activity of covalently immobilised LAC in groups $C_{2}, C_{6}$, and membranes was not only the lower amount of bonded protein but also the stabilisation of the LAC quaternary structure by strong covalent bonds and multipoint attachment to the carrier. This contributed to LAC rigidity and, consequently, loss of activity, which is a well-known disadvantage of this technique $[14,15]$. On the other hand, adsorption of LAC on $\mathrm{C}_{18}$ and $\mathrm{S}_{0}$ carriers is possible through weak hydrogen, hydrophobic, and ionic bonds as well as van der Waals forces, allowing sufficiently strong bonds without any distortion of the structure of the enzyme, which maintains its activity [12]. 
The contribution of different types of bonds formed during the covalent LAC immobilisation was calculated based on the activity of unbonded LAC in eluates obtained during the carrier washing steps (Figure 3). Covalent bonds represented the main type of immobilisation on both groups of carriers, whereas unspecific bonds accounted for up to $12 \%$. The percentage of unspecific bonds ranged from $3.8 \%$ to $12.1 \%$ in the $\mathrm{C}_{2}$ group and from $1.8 \%$ to $4.5 \%$ in the $\mathrm{C}_{6}$ group. The two groups of carriers differed in terms of the proportion of unspecific bonds. There was a clear predominance of adsorption over the other ones in the $\mathrm{C}_{2}$ group, whereas adsorption in the $\mathrm{C}_{6}$ group was negligible.
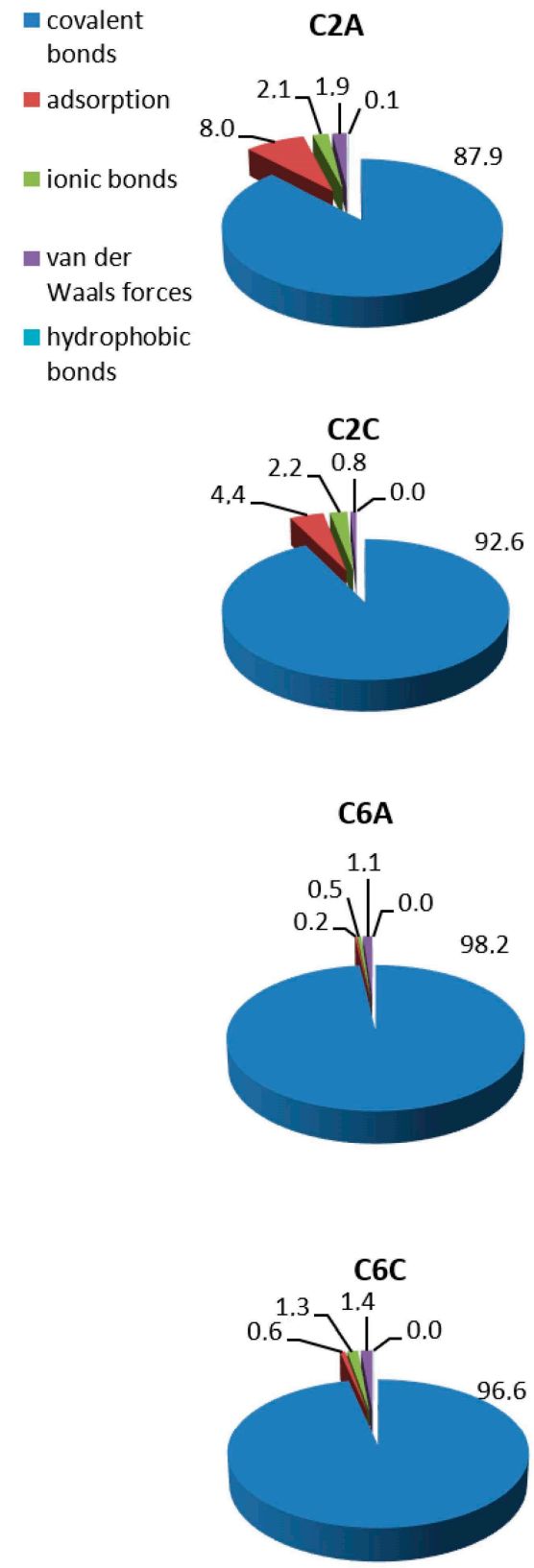

C2B

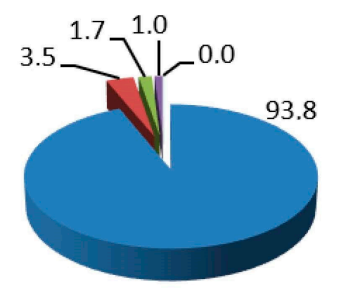

C2D

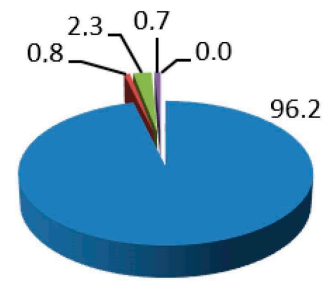

C6B

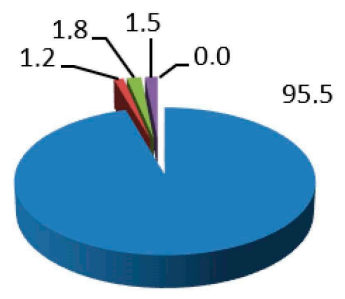

C6D

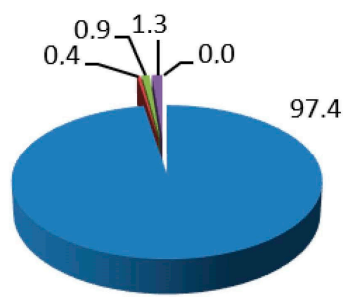

Figure 3. Percentage of bonds formed during immobilisation of LAC on porous carriers with $C_{2}$ and $\mathrm{C}_{6}$ spacer arms.

In the case of the membranes, most LAC was present in the decanted solution remaining after immobilisation, due to the very low bonding on the poorly developed specific surface of the membranes. In the case of the $\mathrm{C}_{18}$ and $\mathrm{S}_{0}$ groups, the adsorption of LAC on the porous carriers was so strong that there was no LAC in the solution decanted over the carriers after the immobilisation. Consequently, 
both factors contributed to the lack of LAC activity in the eluates during washing of the $\mathrm{C}_{18}$ and $\mathrm{S}_{0}$ carriers and the membranes and thus it was not possible to determine the types of bonds formed during LAC immobilisation thereon.

The differences in the immobilised LAC activity depended on the carrier structure and the immobilisation technique, whereas the stability of LAC during long-term storage was not as obvious. Generally, the activity of laccase immobilised covalently on any of the tested carriers remained above $50 \%$ activity after four weeks of storage (Figure 4 ).
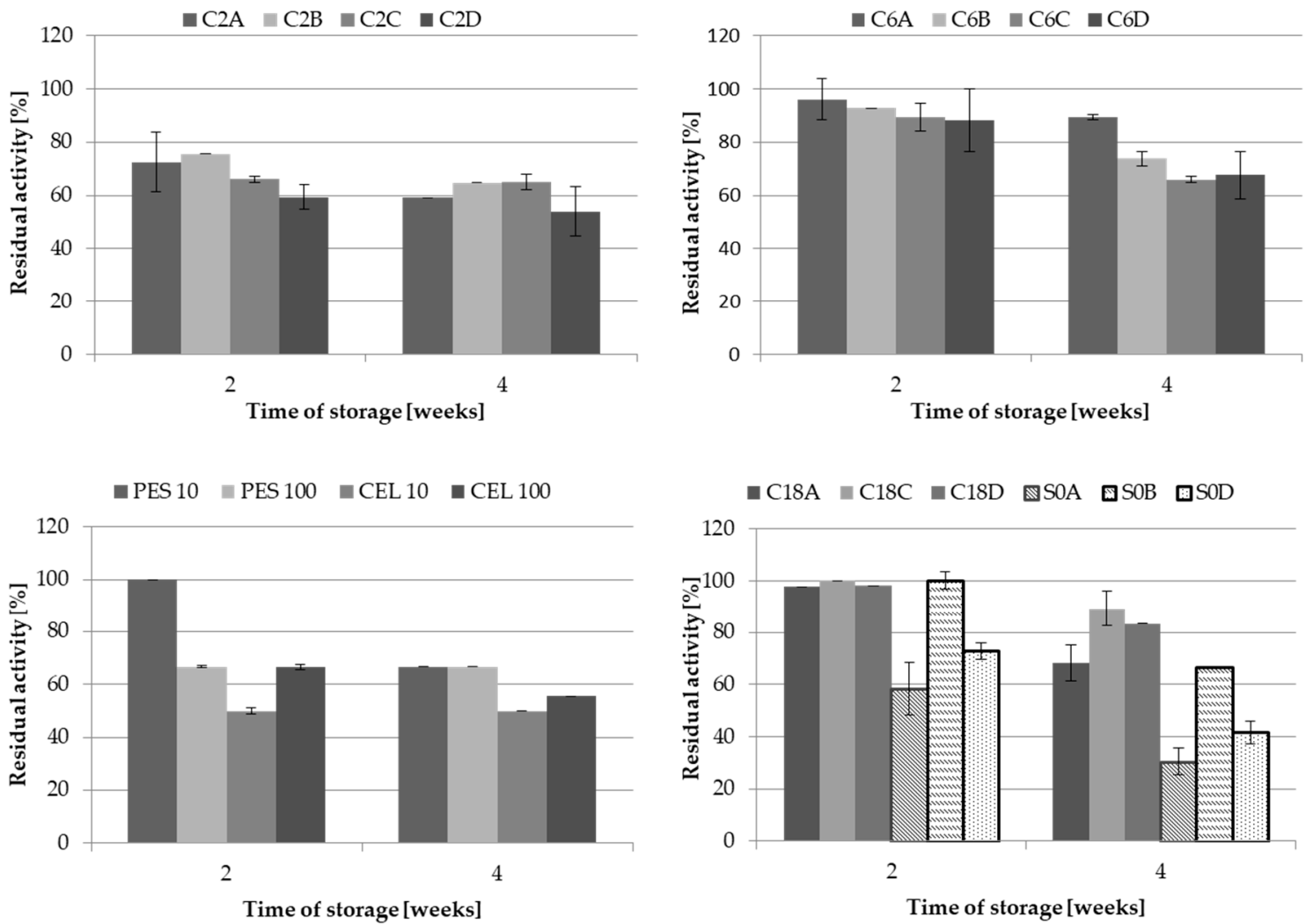

Figure 4. Stability of LAC immobilised on different carriers via covalent bond formation and adsorption during 4 weeks of storage at $4{ }^{\circ} \mathrm{C}$.

LAC immobilised on the C6 supports exhibited the highest stability, as its activity exceed $66 \%$ of the initial value. The results obtained on each carrier in its group were comparable, whereas the following differences in the stability were noted between the groups: $C_{6}$ group $>C_{2}$ group $>$ membranes. High stability of LAC obtained through adsorption was noted in the case all the C18 carriers, with the value in the range from $66 \%$ to $89 \%$ of the initial LAC activity after four weeks of storage. The largest discrepancies in the results were recorded for the $\mathrm{S}_{0}$ group. Only for S0B, the carrier retained LAC activity above $60 \%$, which decreased below $50 \%$ in the case of the S0A and SOD carriers. Moreover, the dense packing of LAC molecules on the SOA and SOD carriers may have favoured desorption of loosely bound molecules, which could not have been stabilised due to the lack of any functional group on the carriers.

\subsection{Immobilisation Conditions}

Based on the screening test, six carriers were selected for further studies, i.e., two carriers made from macroporous styrene (S0A and S0D), three made from methacrylate (C2C, C6C, C18C), and one from cellulose membrane (CEL100).

The impact of four physicochemical factors on immobilisation efficiency was evaluated to obtain high activity of immobilised LAC that allows maximising its biocatalytic potential in biotechnological 
processes. The tested factors included $\mathrm{pH}$ values and the concentration of phosphate buffer as an environment of LAC immobilisation, temperature and time of LAC incubation with the support, and the LAC concentration. In this step of the study, the activity of immobilised laccase expressed in $\mathrm{U} / \mathrm{g}$ was monitored.

\subsubsection{Influence of Phosphate Buffer $\mathrm{pH}$ Value}

Most papers described the use of $0.1 \mathrm{M}$ phosphate buffer $\mathrm{pH} 7$ for protein immobilisation [16,17]. The present results showed a slight effect of the phosphate buffer $\mathrm{pH}$ on the activity of immobilised laccase (Table 2).

Table 2. Influence of phosphate buffer $\mathrm{pH}$ value on the activity of LAC [U/g] from P. ostreatus attached covalently or through adsorption on different porous carriers.

\begin{tabular}{|c|c|c|c|c|c|}
\hline \multirow{2}{*}{ Immobilisation Technique } & \multirow{2}{*}{ Carrier } & \multicolumn{4}{|c|}{ Buffer $\mathrm{pH}$} \\
\hline & & 5 & 6 & 7 & 8 \\
\hline \multirow{3}{*}{ Covalent } & $\mathrm{C} 2 \mathrm{C}$ & $5.41 \pm 0.2$ & $4.88 \pm 0$ & $4.5 \pm 0.3$ & $3.13 \pm 0$ \\
\hline & $\mathrm{C} 6 \mathrm{C}$ & $5.26 \pm 0.2$ & $4.65 \pm 0.2$ & $3.99 \pm 0$ & $3.76 \pm 0$ \\
\hline & CEL100 & $0.45 \pm 0$ & $0.45 \pm 0$ & $0.35 \pm 0$ & $0.23 \pm 0$ \\
\hline \multirow{3}{*}{ Adsorption } & $\mathrm{C} 18 \mathrm{C}$ & $4.78 \pm 0$ & $4.95 \pm 0$ & $5.14 \pm 0$ & $4.72 \pm 0$ \\
\hline & SOA & $1.89 \pm 0$ & $2.06 \pm 0$ & $2.09 \pm 0$ & $1.5 \pm 0$ \\
\hline & SOD & $1.56 \pm 0$ & $1.53 \pm 0$ & $1.32 \pm 0$ & $1.07 \pm 0$ \\
\hline
\end{tabular}

In the case of the covalently attached protein, the highest values were noted after using buffer of pH 5 (C2C and $\mathrm{C} 6 \mathrm{C}$ carriers), which decreased as the buffer $\mathrm{pH}$ increased, whereas the highest activity of laccase adsorbed on the carrier was determined for the $\mathrm{C} 18 \mathrm{C}$ carrier when buffer $\mathrm{pH} 7$ was used (Table 2).

The correlation between buffer $\mathrm{pH}$ and LAC activity in the case of the covalent immobilisation can be the result of the impact of $\mathrm{pH}$ on functional groups, especially on ionisation of hydrogen in primary lysine amino groups on the surface of laccase participating in multipoint attachment, which is more likely to form at higher $\mathrm{pH}$ values [18]. In the case of adsorption on C18C, the elevated $\mathrm{pH}$ may have negatively influenced the octadecyl groups and thus limited the availability of these groups for interaction with laccase molecules. In contrast, the effect of buffer $\mathrm{pH}$ on adsorption on the $\mathrm{S}_{0}$ supports was marginal. However, samples of immobilised LAC obtained in the $\mathrm{pH} 5$ buffer turned out to be unstable. The process of LAC washing out from the carriers was monitored with the Bradford method. After 7 days of storage, the activity of unbounded LAC present in the buffer solution was higher in the case of laccase immobilised in the $\mathrm{pH} 5$ buffer than in the samples obtained at $\mathrm{pH} 7$ and $\mathrm{pH}$ 8. Similar correlations between the buffer $\mathrm{pH}$ value and immobilisation efficiency as well as LAC release from the carrier were observed by Pezzella and co-workers, who noted the highest immobilisation yield of laccase after incubation in phosphate buffer $\mathrm{pH} 7.5$ with no simultaneous desorption of covalently bound laccase $[19,20]$. Considering all these results, $\mathrm{pH} 7$ buffer was selected for further experiments. This is in agreement with literature data reporting that the phosphate $\mathrm{pH} 7$ buffer is an optimal environment for laccase immobilisation, especially when glutaraldehyde is the bi-functional coupling agent [6].

\subsubsection{Temperature and Time of Immobilisation}

From the wide range of parameters that are important for immobilisation process, the temperature and time of incubation with the enzyme should be optimised, because they facilitate reduction of the immobilisation process cost. Most of the enzyme-engaging processes occur at the temperature of $4{ }^{\circ} \mathrm{C}$ to minimise enzyme degradation. Application of $4{ }^{\circ} \mathrm{C}$ for immobilisation of LAC can increase its half-life but can also limit its structure flexibility during attachment to the carrier surface or bond 
formation. The results of the experiment showed the same correlation for all types of carriers used for covalent immobilisation (Table 3).

Table 3. Influence of the temperature on the activity $[\mathrm{U} / \mathrm{g}]$ of covalently immobilised LAC from $P$. ostreatus during 24-h incubation.

\begin{tabular}{cccccc}
\hline \multirow{2}{*}{ Carrier } & Temperature & \multicolumn{4}{c}{ Time of LAC Incubation [h] } \\
\cline { 3 - 6 } & & $\mathbf{1}$ & $\mathbf{3}$ & $\mathbf{5}$ & $\mathbf{2 4}$ \\
\hline \multirow{2}{*}{ C2C } & $4{ }^{\circ} \mathrm{C}$ & $3.43 \pm 0.4$ & $4.73 \pm 0.1$ & $4.26 \pm 0.3$ & $4.44 \pm 0.3$ \\
& $22{ }^{\circ} \mathrm{C}$ & $4.41 \pm 0.2$ & $5.18 \pm 0.1$ & $4.55 \pm 0.2$ & $4.30 \pm 0.4$ \\
\hline \multirow{2}{*}{ C6C } & $4{ }^{\circ} \mathrm{C}$ & $3.91 \pm 0.2$ & $4.16 \pm 0.2$ & $4.37 \pm 0.2$ & $4.38 \pm 0.7$ \\
& $22{ }^{\circ} \mathrm{C}$ & $4.55 \pm 0.2$ & $4.61 \pm 0.4$ & $3.72 \pm 0.2$ & $4.01 \pm 0.6$ \\
\hline \multirow{2}{*}{ CEL100 } & $4{ }^{\circ} \mathrm{C}$ & $0.55 \pm 0.1$ & $0.63 \pm 0.1$ & $0.61 \pm 0$ & $0.83 \pm 0.1$ \\
& $22^{\circ} \mathrm{C}$ & $0.73 \pm 0$ & $0.68 \pm 0$ & $0.78 \pm 0.1$ & $0.83 \pm 0.1$ \\
\hline \multirow{2}{*}{ C18C } & $4{ }^{\circ} \mathrm{C}$ & $4.02 \pm 0.2$ & $3.97 \pm 0.2$ & $3.63 \pm 0.5$ & $4.44 \pm 0.3$ \\
& $22{ }^{\circ} \mathrm{C}$ & $4.22 \pm 0$ & $4.37 \pm 0.2$ & $4.01 \pm 0.5$ & $4.59 \pm 0.1$ \\
\hline \multirow{2}{*}{ S0A } & $4{ }^{\circ} \mathrm{C}$ & $2.20 \pm 0.1$ & $2.15 \pm 0.1$ & $2.26 \pm 0.1$ & $2.33 \pm 0.3$ \\
& $22{ }^{\circ} \mathrm{C}$ & $2.06 \pm 0$ & $2.63 \pm 0.2$ & $2.13 \pm 0.1$ & $2.51 \pm 0.2$ \\
\hline \multirow{2}{*}{ S0D } & $4{ }^{\circ} \mathrm{C}$ & $2.40 \pm 0.1$ & $2.44 \pm 0.1$ & $2.57 \pm 0.1$ & $2.40 \pm 0.1$ \\
& $22{ }^{\circ} \mathrm{C}$ & $2.33 \pm 0$ & $2.99 \pm 0.2$ & $2.41 \pm 0.2$ & $2.83 \pm 0.2$ \\
\hline
\end{tabular}

The activity of LAC obtained after incubation at $4{ }^{\circ} \mathrm{C}$ was lower than in preparations incubated at $22{ }^{\circ} \mathrm{C}$, especially during the first $3 \mathrm{~h}$ of incubation; these differences became less significant in the following hours. The optimal time of carrier incubation with the LAC protein varied and depended on the carrier used: it was $3 \mathrm{~h}$ for four out of the six carriers. The LAC activities obtained at $22{ }^{\circ} \mathrm{C}$ were higher in comparison to their analogue obtained at $4{ }^{\circ} \mathrm{C}$. This may suggest that, after more than $3 \mathrm{~h}$ of incubation, the concentration of protein bound to the carrier was too high and restrained dispersion of the substrate and the product [21]. This effect was also observed in the case of the covalent immobilisation of Pleurotus florida laccase, where incubation of the enzyme with the porous silica perlite carrier for more than $4 \mathrm{~h}$ had no effect on a further increase in the immobilisation yield and the activity of immobilised LAC [19].

\subsubsection{Laccase Concentration}

The purified laccase from Pleurotus ostreatus was immobilised in optimal conditions in a concentration range from $0.5 \mathrm{mg} / \mathrm{g}$ to $4 \mathrm{mg} / \mathrm{g}$ of the wet mass of the carrier. As presented in Table 4 , the concentration of LAC bound to the carrier had a significant impact on enzymatic activity.

Table 4. Effect of the LAC concentration applied for covalent immobilisation (C2C, C6C, CEL100) and via adsorption (C18C, S0A) on the activity of immobilised LAC [U/g]; optimal conditions were: buffer $\mathrm{pH} 7$, buffer concentration- $0.025 \mathrm{M}$ for $\mathrm{C} 2 \mathrm{C}$ and $0.1 \mathrm{M}$ for $\mathrm{C} 6 \mathrm{C}$, time and temperature of incubation-3 $\mathrm{h}$ and $22^{\circ} \mathrm{C}$.

\begin{tabular}{ccccc}
\hline \multirow{2}{*}{ Carrier } & \multicolumn{4}{c}{ LAC Concentration $[\mathbf{m g} / \mathbf{g}]$} \\
\cline { 2 - 5 } & $\mathbf{0 . 5 / 0 . 2 5 *}$ & $\mathbf{1 / 0 . 5}$ & $\mathbf{2 / 0 . 7 5}$ & $\mathbf{4}$ * ${ }^{*}$ \\
\hline C2C & $5.38 \pm 0.3$ & $12.18 \pm 0$ & $8.14 \pm 0.3$ & $19.14 \pm 0$ \\
C6C & $3.82 \pm 0.5$ & $5.79 \pm 0.2$ & $10.73 \pm 1.3$ & $14.09 \pm 1.4$ \\
CEL100 & $0.74 \pm 0$ & $0.77 \pm 0.2$ & $0.92 \pm 0.1$ & $0.97 \pm 0.1$ \\
C18C & $5.56 \pm 0$ & $7.51 \pm 0.6$ & $5.31 \pm 0.2$ & $5 \pm 0.5$ \\
S0A & $1.51 \pm 0.1$ & $3.13 \pm 0.1$ & $3.27 \pm 0.2$ & $3.56 \pm 0.4$ \\
\hline \multicolumn{5}{c}{ * values of LAC concentration only for CEL100. }
\end{tabular}


The application of the higher concentration of LAC in the solution resulted in higher activity of immobilised LAC (Table 4). The protein overcrowding on the carrier surface, affecting the activity of immobilised laccase, is a well-known phenomenon, which limits the full use of carrier capacity. For example, the declared capacity of most of the tested Purolite ${ }^{\circledR}$ carriers is estimated at $50 \mathrm{mg}$ of protein per $1 \mathrm{~g}$ of carrier. The present results of immobilised LAC activity clearly indicated that this concentration was far too high for the majority of carriers and did not affect the activity of the obtained laccase proportionally. A drastic decrease in the efficiency after covalent binding of laccase was observed, where the immobilisation yield dropped from $70 \%$ to $50 \%$ for preparations with $80 \mathrm{IU} / \mathrm{g}$ and $300 \mathrm{IU} / \mathrm{g}$ loading, respectively [19]. Overloading of the support is a well-known phenomenon, in which a high number of enzyme molecules limit the dispersion of the substrate and reaction product [22].

\subsection{Storage Conditions and Thermostability}

\subsubsection{Composition and $\mathrm{pH}$ Value of Buffer}

The impact of the buffer composition and its $\mathrm{pH}$ value on the activity of both free and immobilised LAC was evaluated during 4-week storage. The results showed that immobilisation of LAC significantly improved its stability (Figure 5).
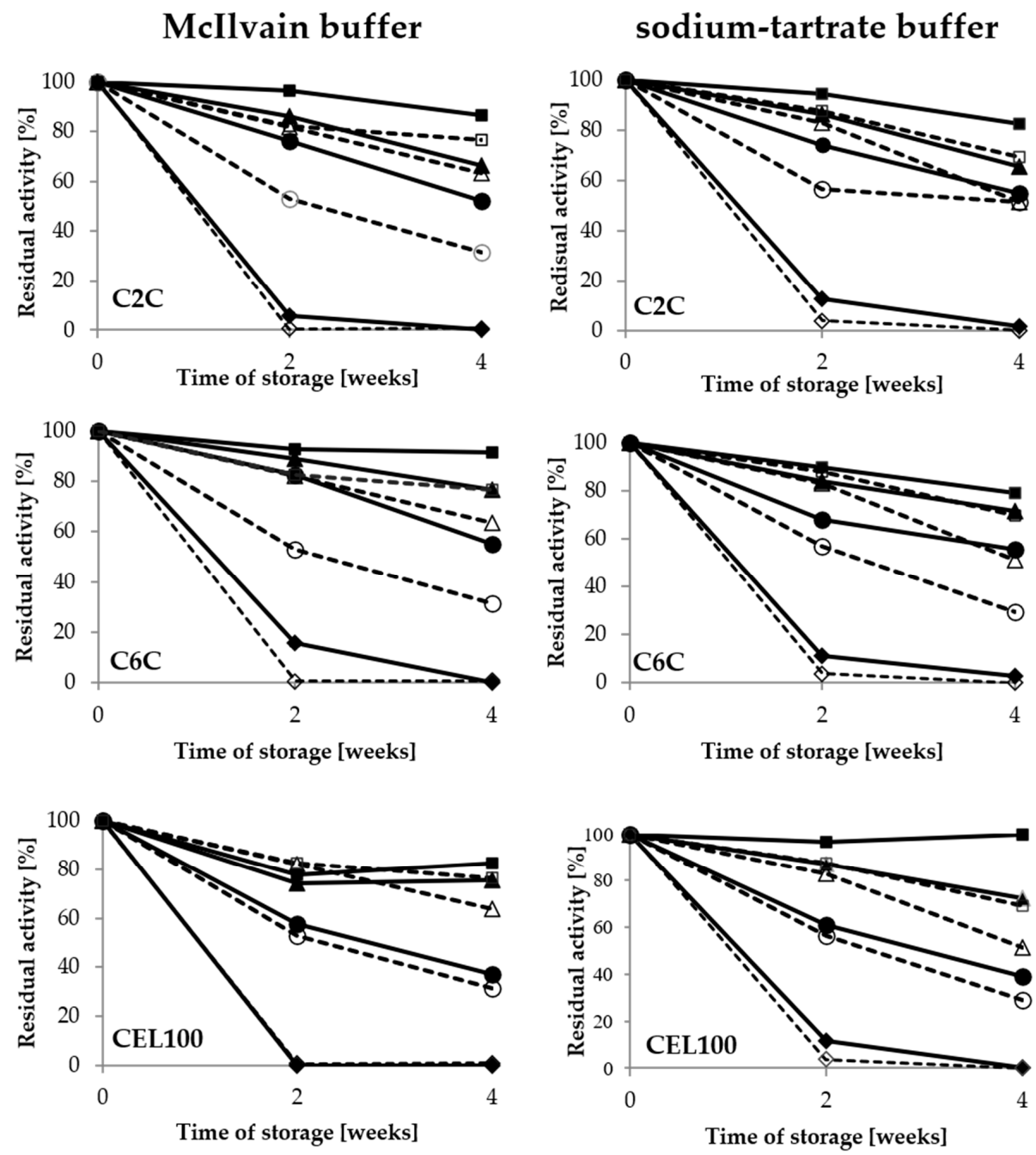

Figure 5. Stability of covalently immobilised laccase activity during 4-week storage in the McIlvain buffer and sodium-tartrate buffer in the range of $\mathrm{pH}$ values from 3 to 6; immobilised LAC—filled, free LAC—empty: $\mathrm{pH} 3$-rhombus, $\mathrm{pH} 4$ - circle, $\mathrm{pH}$ 5-triangle, $\mathrm{pH}$ 6-square. 
Moreover, it was noted that $\mathrm{pH}$ value of buffer had a significant impact on the activity of immobilised LAC during the long-term storage. In the case of the covalent immobilisation, the optimal buffer for storage of both immobilised and free LAC was $\mathrm{pH}$ 6, with a minimum influence of the buffer composition. In the case of the porous $\mathrm{C} 2 \mathrm{C}$ and $\mathrm{C} 6 \mathrm{C}$ carriers, the highest stability of laccase was observed after using the Mcllvain buffer, with $87 \%$ and $91 \%$ of retained activity respectively, after four weeks of storage (Figure 5). Therefore, this buffer was selected for further studies of laccase immobilised on those carriers, while the $\mathrm{pH} 6$ sodium-tartrate buffer was selected for the CEL100 membrane as the best for preservation of the activity of immobilised laccase.

In the case of the adsorbed laccase, the $\mathrm{pH}$ value was the most important factor for the enzyme stability as well; however, the composition of the buffer altered the optimal $\mathrm{pH}$ value. As shown in Figure 6, the activity of laccase adsorbed on the C18C carrier varied between the different storage buffer types (Figure 6). The highest values for the McIlvain buffer were noted after storage at $\mathrm{pH} 6$, whereas the peak of activity in the sodium-tartrate buffer was observed after storage at pH 5 .
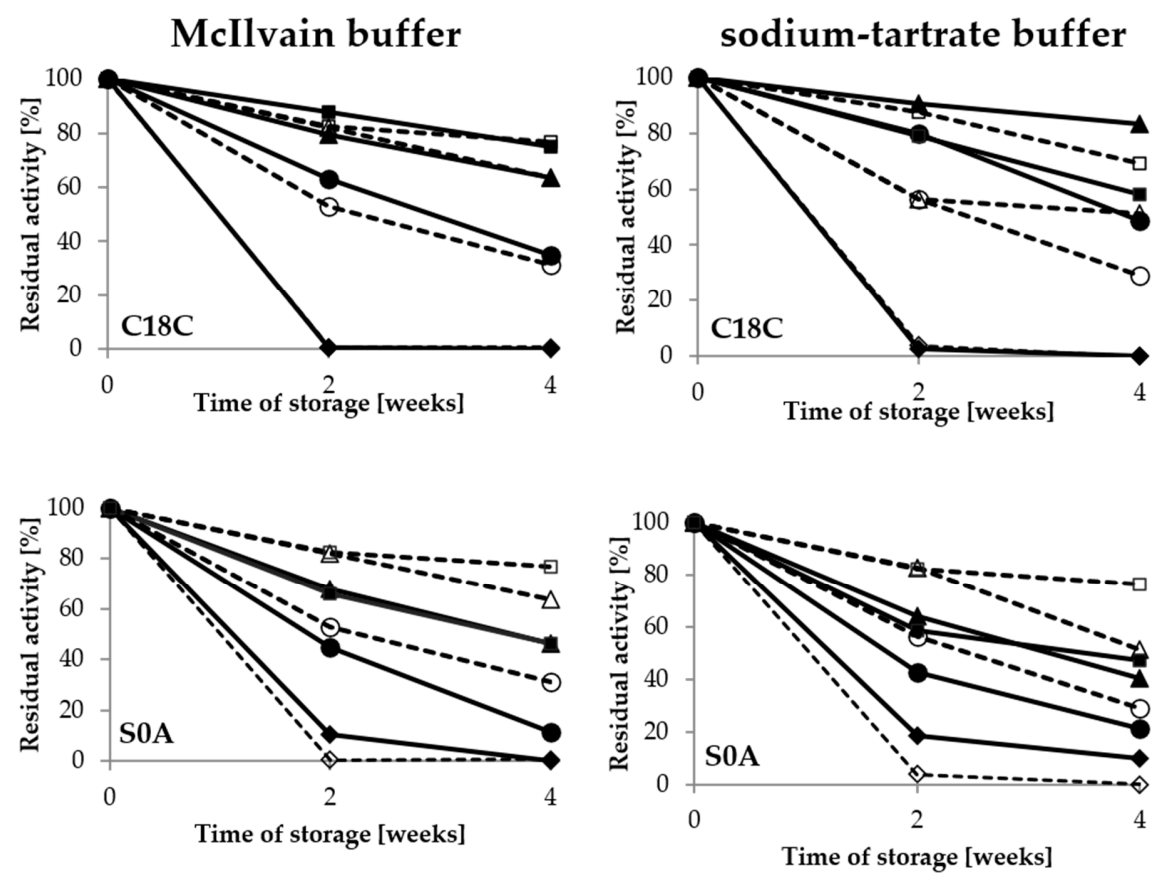

Figure 6. Stability of adsorbed laccase activity during 4-week storage in the McIlvain buffer and the sodium-tartrate in the range of $\mathrm{pH}$ from 3 to 6; immobilised LAC—filled, free LAC-empty: $\mathrm{pH}$ 3-rhombus, $\mathrm{pH} 4$-circle, $\mathrm{pH}$ 5-triangle, $\mathrm{pH} 6$-square.

For laccase adsorbed on the S0A carrier, high activity was also noted in the $\mathrm{pH} 5$ sodium-tartrate buffer, but only after 2 weeks of storage. Immobilisation of laccase preserved its activity in comparison with the free form of the enzyme. The results regarding the beneficial effect of immobilisation on LAC activity preservation in adverse conditions during storage are consistent with those reported for inter alia Trametes versicolor laccase immobilised covalently on metal-ion-chelated magnetic microspheres and silica beads $[23,24]$ and laccase adsorbed on vinyl-modified mesoporous fibres or on carbon-based mesoporous magnetic composites [25,26].

\subsubsection{Thermostability}

One of the main goals of laccase immobilisation is to increase its resistance to adverse environmental conditions such as high temperature. In this experiment, free and immobilised laccase was incubated in the temperature range from $20^{\circ} \mathrm{C}$ to $80^{\circ} \mathrm{C}$ for $24 \mathrm{~h}$ to assess its stability. The results indicated that the immobilisation of laccase improved its stability, compared to the free form (Figure 7). In the case of covalent immobilisation, the highest activity of both immobilised and free laccase was maintained after 
refrigerated storage and decreased along with the increase in the temperature up to $50{ }^{\circ} \mathrm{C}$, above which protein denaturing conditions were observed. Among the tested covalent carriers, $\mathrm{C} 2 \mathrm{C}$ exhibited the highest stability of immobilised laccase in the range of approx. $90 \%$ to $50 \%$ of the initial activity at the temperature of $20{ }^{\circ} \mathrm{C}$ to $40{ }^{\circ} \mathrm{C}$ respectively, which constituted a $20 \%$ to $11 \%$ difference compared to free laccase (Figure 7). The better thermostability results of the $\mathrm{C} 2 \mathrm{C}$ samples may have been caused by the formation of multipoint bonds, which are more likely to form when functional groups are mounted on the short spacer and prevent denaturation of the enzyme [18,27]. This feature has been repeatedly described in the literature for different laccases and supports $[13,23,27]$.
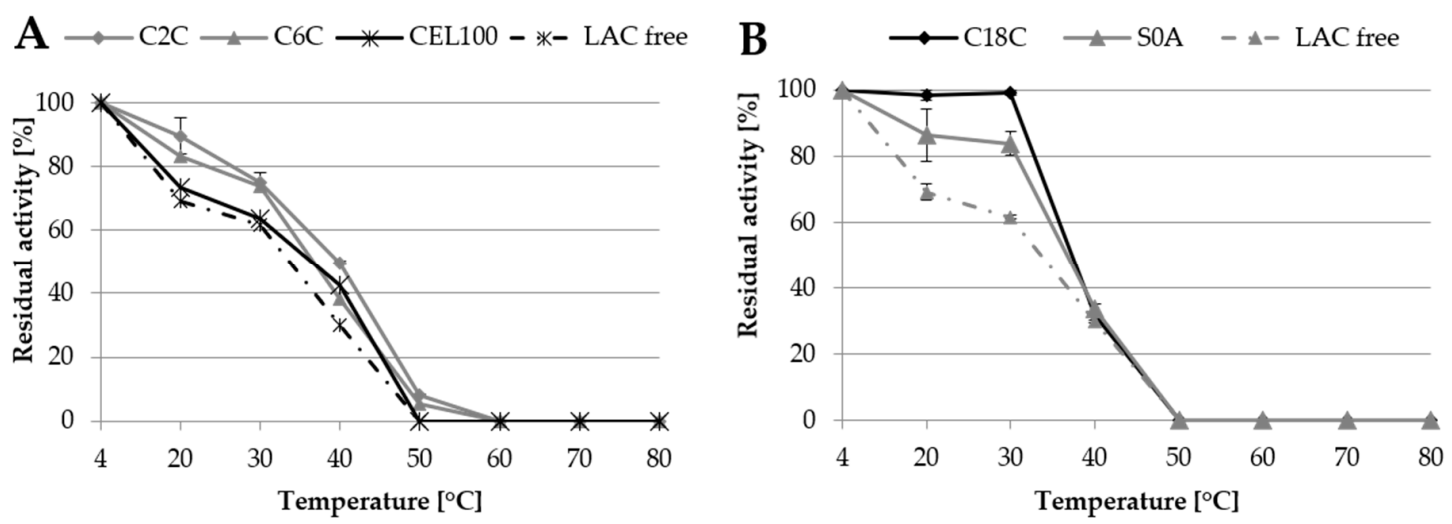

Figure 7. Thermostability of laccase immobilised covalently (A) and via adsorption (B) in comparison to thermostability of free laccase (LAC free).

The activity of laccase adsorbed on the $\mathrm{C} 18 \mathrm{C}$ and S0A carriers was maintained much longer than in the case of the covalent immobilisation. In this case, the results showed approx. $99 \%$ and $85 \%$ of laccase initial activity at $20^{\circ} \mathrm{C}$ and $30^{\circ} \mathrm{C}$, respectively. However, at $40{ }^{\circ} \mathrm{C}$, the stability of the immobilised laccase decreased drastically, even more than that of the free form of the enzyme, which probably resulted from the low stability of the carriers themselves at high temperatures.

\subsection{Degradation of Bisphenol A}

Bisphenol A (BPA) is a well-known organic pollutant identified mainly in the aquatic environment [28]. Numerous studies have shown that BPA present in drinking water enters the human organism and is contained mainly in human body fluids such as urine, umbilical cord blood, and breast milk $[29,30]$. Such distribution poses a threat to human health already at the stage of foetal life, since the main harmful effect of BPA is hormonal disorders of the reproductive system [31]. In adults, it leads to infertility in general but also to prostate cancer in men and ovarian cancer in women [32]. Therefore, transformation of BPA is important in terms of limitation of its concentration in wastewater, its distribution in environment, and harmful effects on living organism. Therefore, the potential of immobilised LAC to degrade BPA was assessed.

Samples of immobilised LAC were tested as a potential catalyst for bisphenol A degradation. In the first stage of the experiments, several concentrations of BPA from $0.5 \mathrm{mg} / \mathrm{L}$ to $10 \mathrm{mg} / \mathrm{L}$ were transformed using immobilised LAC with activity of $5 \mathrm{U} / \mathrm{L}$. After $72 \mathrm{~h}$ of transformation, the BPA depletion ranged from $50 \%$ to even $100 \%$ in the case of the $\mathrm{C} 2 \mathrm{C}$ carrier and the $\mathrm{C} 18 \mathrm{C}$ carrier, respectively (Figure 8). To distinguish the enzymatic transformation from physical adsorption of BPA, a control experiment regarding BPA adsorption was conducted. The results prompt a conclusion that the depletion of BPA by most of the carriers is mainly due to adsorption of the compound. This was especially visible in the case of the $100 \%$ removal by the C18C carrier, probably caused by the presence of octadecyl groups and thus the hydrophobic nature of this carrier, to which BPA as a substance sparingly soluble in water attaches easily. In the case of the $\mathrm{C} 2 \mathrm{C}$ and $\mathrm{C} 6 \mathrm{C}$ carriers exhibiting the same porosity and particle size, but different functional groups BPA adsorption was no higher than $70 \%$. 
Interestingly, no BPA adsorption on the CEL100 carrier was observed, and the BPA loss was caused only by the LAC transformation.

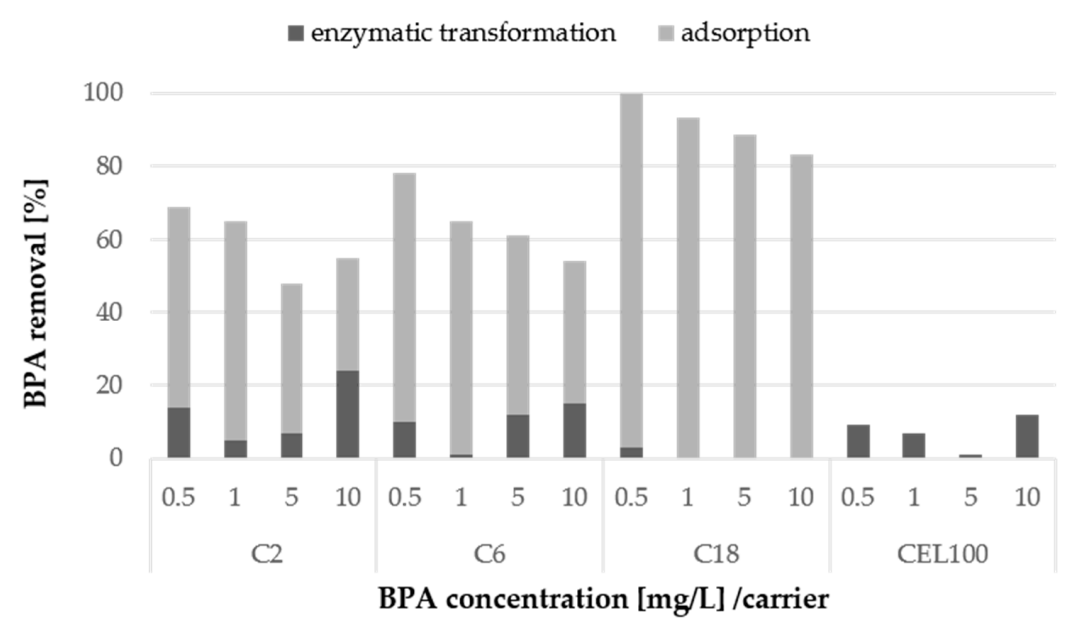

Figure 8. Enzymatic transformation of BPA at a concentration from $0.5 \mathrm{mg} / \mathrm{L}$ to $10 \mathrm{mg} / \mathrm{L}$ using adsorbed or covalently immobilised laccase and removal of BPA via adsorption on the surface of non-modified selected carriers after $72 \mathrm{~h}$. The standard error of the results did not exceed $5 \%$.

Among the tested BPA concentrations, the highest percent of enzymatic transformation for $10 \mathrm{mg} / \mathrm{L}$ BPA was observed in the case of the C2 and C6 carriers with covalently immobilised LAC. It could be expected that the highest percentage of transformation would be observed at a lower concentration of BPA. However, the results suggested that most of the BPA sample in the case of the lower concentration was probably strongly adsorbed on the carrier and thus the transformation was inhibited.

To maximise the BPA transformation using immobilised LAC, the higher activity of $12 \mathrm{U} / \mathrm{L}$ was applied. This increased the share of enzymatic transformation over adsorption in the BPA loss up to 39\%, $45 \%$ and $21 \%$ for the C2C carrier, the C6C carrier, and the CEL100 membrane, respectively (Figure 9). The best rate of BPA enzymatic degradation obtained for the $\mathrm{C} 6 \mathrm{C}$ carrier was $45 \%$, which corresponds to $0.063 \mathrm{mg} / \mathrm{L} / \mathrm{h}$ of BPA removal. This result was comparable to results obtained for laccase from Trametes versicolor immobilised on Hippospongia communis, i.e., $0.08 \mathrm{mg} / \mathrm{L} / \mathrm{h}$ of BPA removal, and even higher than those reported for Coriolopsis gallica laccase immobilised on silica beads $(>0.03 \mathrm{mg} / \mathrm{L} / \mathrm{h}$ of BPA removal) $[33,34]$. Noteworthy, our results were obtained using nearly 5-times lower LAC activity than the activity of $C$. gallica LAC [33].

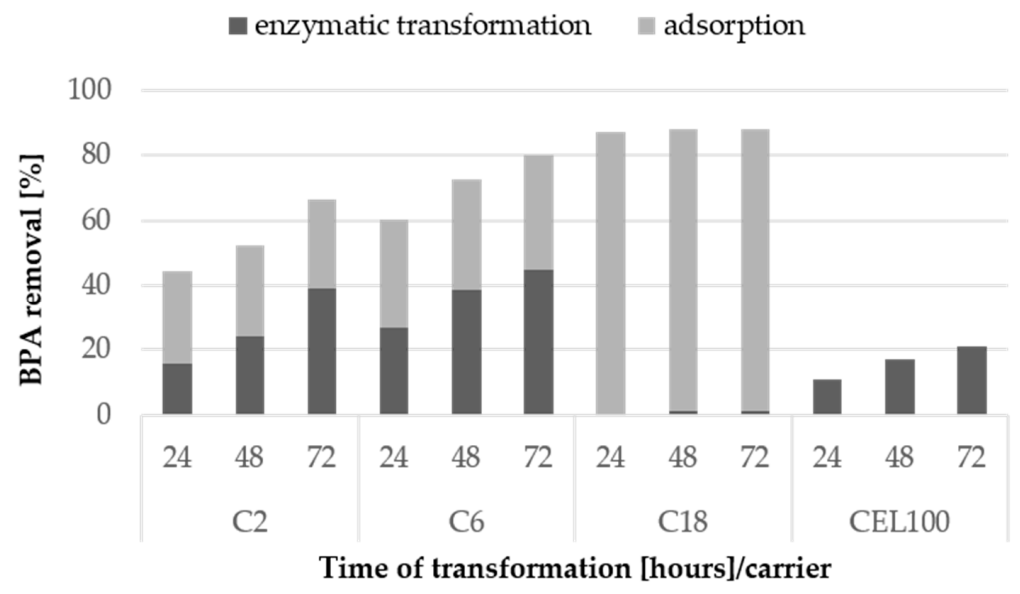

Figure 9. Enzymatic transformation and adsorption of BPA at the concentration of $10 \mathrm{mg} / \mathrm{L}$ using laccase immobilised covalently and via adsorption on selected carriers after 24,48 and $72 \mathrm{~h}$. The standard error of the results did not exceed $5 \%$. 
In the case of the $\mathrm{C} 18 \mathrm{C}$ carrier, the increase in the LAC activity resulted in lack of transformation, even though the LAC activity on this carrier was the highest and the mass of the carrier used in the transformation was the lowest. Therefore, it may be concluded that carriers with LAC immobilised by adsorption are not suitable in BPA and other partially soluble in water substances transformation, even though they exhibit high activity of LAC attached.

The main advantage of immobilised laccase application is its reusability, what was measured during 10 batches of BPA (final concentration $10 \mathrm{mg} / \mathrm{L}$ ) transformed by covalently immobilised LAC. From four previously tested carriers, the $\mathrm{C} 18 \mathrm{C}$ carrier was excluded due to the high adsorption of the BPA. The highest BPA removal was obtained for $\mathrm{C} 6 \mathrm{C}$ carrier in the first five batches comparing to $\mathrm{C} 2 \mathrm{C}$ carrier (Figure 10A). In next batches, BPA removal rate was equal for both carriers. The lowest reusability was showed for CEL100 membrane, probably due to low surface area, which is a disadvantage of membranes application [17]. Along with BPA removal activity of immobilised LAC activity also decreased (Figure 10B) and retained about $50 \%$ of its initial activity in the fourth batch, which is comparable to activity of laccase immobilised in cross-linked aggregates and metal-ion-chelated magnetic microspheres [24,35].
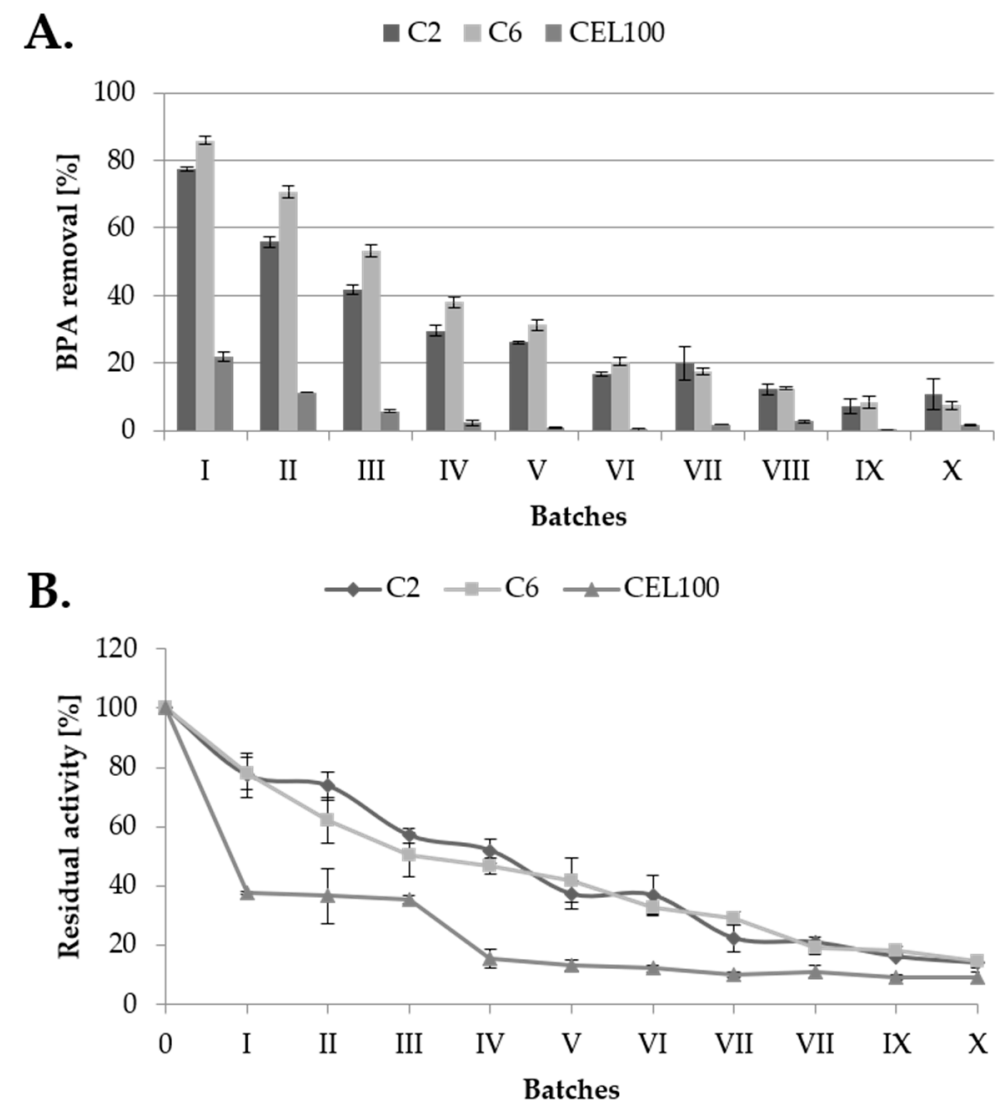

Figure 10. Rate of bisphenol A transformation during ten subsequent batches (A) and residual LAC activity (B) measured on the tested C2, C6 and CEL100 carriers.

\subsection{Toxicity Evaluation}

Biological degradation of micropollutants including enzymatic treatment generates reaction intermediates with varied biological activity [36]. Moreover, in some cases, products of reaction may be equally or even more toxic than the treated substrate [37].

Therefore, it is important to ensure that the transformation process is not only effective but also mitigates the hazardous effect of the micropollutant. Since BPA mostly accumulates in the environment, the ecotoxicity of BPA and its transformation products was evaluated and, since it pollutes drinking 
water and enters the human body through ingestion, its cytotoxicity towards normal colon epithelial cells tests was assessed.

The ecotoxicity was tested using a Microtox ${ }^{\circledR}$ test based on inhibition of bioluminescence of bacterial species Vibrio fisheri, which is one of the most common standardised methods used in ecotoxicity assessment [38]. The results of the $\mathrm{EC}_{50}$ values indicated that BPA transformation products are ca. 2.5-times less toxic than the BPA substrate (Table 5). These results are consistent with results of BPA degradation with crude laccase from P. ostreatus, which reduced BPA toxicity to $4.65 \%$ of its initial value [39].

Table 5. Environmental toxicity of BPA and its transformation products obtained using Microtox ${ }^{\circledR}$ test after 5 and 15 min of incubation with Vibrio fisheri and expressed as $\mathrm{EC}_{50}$.

\begin{tabular}{ccc}
\hline \multirow{2}{*}{ Time } & \multicolumn{2}{c}{$\mathrm{EC}_{\mathbf{5 0}}[\mathrm{mg} / \mathrm{L}]$} \\
\cline { 2 - 3 } & BPA & Products \\
\hline $5 \mathrm{~min}$ & $0.116 \pm 0$ & $0.316 \pm 0.01$ \\
$15 \mathrm{~min}$ & $0.156 \pm 0.01$ & $0.375 \pm 0.02$ \\
\hline
\end{tabular}

The MTT test showed no effect of BPA and its transformation products on mitochondrial activity after $24 \mathrm{~h}$ of incubation with colon epithelial cells CCD-841CoTr (Table 6). After $48 \mathrm{~h}$ of incubation, a decrease in the toxicity of the product compared to the substrate was noticeable but both values were still low.

Table 6. Cytotoxicity effect of BPA and its transformation products after 24 and $48 \mathrm{~h}$ of incubation with human colon cells evaluated using MTT and LDH tests and expressed as \% of damaged cells.

\begin{tabular}{ccccc}
\hline \multirow{2}{*}{ Time } & \multicolumn{2}{c}{ MTT } & \multicolumn{2}{c}{ LDH } \\
\cline { 2 - 5 } & BPA & Products & BPA & Products \\
\hline $24 \mathrm{~h}$ & 0 & 0 & $15 \pm 1.82$ & $5 \pm 0.23$ \\
$48 \mathrm{~h}$ & $10 \pm 0.77$ & $7 \pm 1.23$ & $17 \pm 2.5$ & $3 \pm 0.71$ \\
\hline
\end{tabular}

Thus, it may be assumed that BPA and its transformation product had a limited influence on cell metabolic activity at the concentration of $4 \mathrm{mg} / \mathrm{L}$; this corresponds to the concentration of $17 \mathrm{mM}$, which was still over million times higher than that in drinking and surface water [40]. Lan et al. reached similar conclusions after application of the MTT test of BPA in MA-10 cells. They showed that BPA at a concentration lower that $100 \mu \mathrm{M}$ had no apoptotic effect as well as a long-term use of a low dose BPA below $1 \mu \mathrm{M}$ [41]. On the contrary, the MTT test showed that a low dose of BPA in the range from $0.1 \mathrm{nM}$ to $10 \mu \mathrm{M}$ stimulated proliferation of breast cancer MCF-7 and SkBr-3 cells, which is consistent with the suggestion that even such a low dose of BPA exposure may lead to development of breast cancer [42]. On the other hand, the tested concentration was sufficient to induce damage to the plasma membrane demonstrated in the LDH test. After $24 \mathrm{~h}$ of incubation, the results for BPA showed a 15\% cytotoxic effect, which decreased in the case of the BPA product obtained after the immobilised LAC treatment to $5 \%$. Therefore, it can be argued that cell exposure to BPA causes a certain degree of membrane damage first; however, the metabolic activity of cells is retained for some time.

\section{Materials and Methods}

\subsection{Microorganism and Culture Conditions}

The source of extracellular laccase (LAC) was the white rot fungus Pleurotus ostreatus (PO13) obtained from the Fungal Collection of the Department of Biochemistry and Biotechnology, Maria Curie-Skłodowska University (Lublin, Poland). The Pleurotus ostreatus strain was cultivated on Petri dishes containing maltose agar medium (glucose $20 \mathrm{~g} / \mathrm{L}$, maltose extract $20 \mathrm{~g} / \mathrm{L}$, peptone $1 \mathrm{~g} / \mathrm{L}$, 
agar $20 \mathrm{~g} / \mathrm{L}$ ), for 10 days in $25^{\circ} \mathrm{C}$ and stored in $4{ }^{\circ} \mathrm{C}$ afterwards. The four $10 \mathrm{~mm}$ plugs of mycelium were transferred to the $250 \mathrm{~mL}$ flasks containing $100 \mathrm{~mL}$ of PDB medium (glucose $20 \mathrm{~g} / \mathrm{L}$, potato extract $4 \mathrm{~g} / \mathrm{L}$ ), and the culture was conducted for 14 days, which was used as inoculum for liquid culture of Pleurotus ostreatus. The liquid culture was conducted in volume of $7 \mathrm{~L}$, in Lindeberg-Holm medium modified by addition of peptone $(0.5 \mathrm{~g} / \mathrm{L})$ with idle air supplied (flow $3.5 \mathrm{~mL} / \mathrm{min}$ ). The laccase was obtained after 12 days of cultivation [43]. Culture liquid was concentrated by ultrafiltration using a Millipore polyethersulfone membrane $(10 \mathrm{kDa})$ and purified by ion exchange chromatography (HQ-Sepharose) using $1 \mathrm{M}\left(\mathrm{NH}_{4}\right)_{2} \mathrm{SO}_{4}$ in TRIS- $\mathrm{HCl}(5 \mathrm{mM})$ with a linear grade from 0 to $50 \%$. Purified laccase was desalted, concentrated, and stored frozen at $-18^{\circ} \mathrm{C}$ until use for preparation of working LAC with precise activity.

\subsection{Chemicals, Reagents, and Carriers}

Glucose, sodium hydroxide, cytric acid, tris(hydroxymethyl)aminomethane (TRIS), and amonium sulphate were purchased from Avantor Performance Materials (Gliwice, Poland). 2,2-Azino-bis (3-ethylbenzthiazoline-6-sulphonic acid) (ABTS), glutaraldehyde, (3-aminopropyl) triethoxysilane bovine serum albumin (BSA), bisphenol A, the MTT dye, the LDH assay kit, and tartaric acid were purchased from Merck-Sigma-Aldrich Company (St. Louis, MO, USA). Porous carriers used for laccase immobilisation were purchased from Purolite ${ }^{\circledR}$ (Gdynia, Poland) whereas polyeterosulphone and cellulose membranes used for LAC immobilisation were purchased from Merck.

\subsection{Catalysts}

The activity of free or immobilised LAC was determined spectrophotometrically by oxidation of $2.5 \mathrm{mM} \mathrm{2,2'-azino-bis-(3-ethylbenzthiazoline-6-sulphonic} \mathrm{acid)} \mathrm{(ABTS)} \mathrm{in} 100 \mathrm{mM}$ Na-tartrate buffer at $\mathrm{pH} 3$. The formation of ABTS+ was monitored spectrophotometrically at $414 \mathrm{~nm}$ $\left(\lambda 414=34,450 \mathrm{M}^{-1} \mathrm{~cm}^{-1}\right)$. Laccase activity was expressed in $\mathrm{U}$ per litre $(\mathrm{U} / \mathrm{L})$. One unit of LAC (U) oxidised $1 \mu \mathrm{mol}$ of ABTS per $1 \mathrm{~min}$ at $25^{\circ} \mathrm{C}$. In the case of immobilised LAC, 5-10 mg samples of the carrier were placed into a stirred vessel containing a three-fold higher volume of buffer and ABTS than the free laccase activity assay; the reaction was monitored using a Cary 50 Bio spectrophotometer (Varian, Pao Alto, CA, USA) equipped with a Peltier stirring module. The activity of immobilised LAC was expressed in Units per gram of the carrier $(\mathrm{U} / \mathrm{g})$. The concentration of LAC was evaluated using the Bradford method.

\subsection{Immobilisation of $L A C$}

Purified LAC from Pleurotus ostreatus was immobilised covalently and through adsorption using the method developed by Bryjak and Rekuć, respectively $[44,45]$. For covalent immobilisation, acrylic supports with amino groups $\left(\mathrm{C}_{2}\right.$ and $\left.\mathrm{C}_{6}\right)$ as well as silanised polyeterosulphone (PES) and cellulose membranes (CEL) were used. The silanisation procedure involved $30 \mathrm{~min}$ shaking of membranes scraps in a $5 \%$ acetone silane solution $(10 \mathrm{~mL}$ per $1 \mathrm{~g}$ of membranes scraps) and drying at $45^{\circ} \mathrm{Cduring}$ the night. In the case of the adsorption technique, macroporous styrene $\left(\mathrm{S}_{0}\right)$ and acrylic beads with octadecyl groups $\left(\mathrm{C}_{18}\right)$ were used. The characteristics of the carriers and immobilisation techniques are shown in Table 7. The numbers used in the acronyms of the carrier names refer to the number of carbon atoms on the carrier surface. In the case of carriers $C_{2}$ and $C_{6}$, it is the length of the spacers: short, built of two carbon atoms, and long, built of six carbon atoms, both ending with an amino group. In the case of the $\mathrm{C} 18$ carriers, there were 18-carbon chains as octadecyl groups. There were no functional groups on the surface of $S_{0}$ carriers. In turn, the numbers used in the acronyms of membranes PES and CEL refer to the pore size: $10 \mathrm{kDa}$ or $100 \mathrm{kDa}$ (Table 7). 
Table 7. Characteristics and acronyms of tested carriers.

\begin{tabular}{|c|c|c|c|c|c|c|}
\hline $\begin{array}{l}\text { Group of } \\
\text { Carriers }\end{array}$ & $\begin{array}{l}\text { Immobilisation } \\
\text { Technique }\end{array}$ & Type of Carriers & $\begin{array}{l}\text { Functional } \\
\text { Groups }\end{array}$ & $\begin{array}{l}\text { Pore Diameter } \\
\text { (§) }\end{array}$ & Particle Size $(\mu \mathrm{m})$ & Acronym \\
\hline \multirow{14}{*}{ Porous } & \multirow{8}{*}{$\begin{array}{l}\text { Covalent } \\
\text { (C2 and C6 } \\
\text { carriers) }\end{array}$} & \multirow{4}{*}{$\begin{array}{l}\text { Amino C2 } \\
\text { methacrylate }\end{array}$} & \multirow{4}{*}{$\begin{array}{c}\mathrm{NH}_{2} \\
\text { (short spacer) }\end{array}$} & \multirow{2}{*}{$300-600$} & $150-300$ & $\mathrm{C} 2 \mathrm{~A}$ \\
\hline & & & & & $300-710$ & C2B \\
\hline & & & & \multirow{2}{*}{$1200-1800$} & $150-300$ & $\mathrm{C} 2 \mathrm{C}$ \\
\hline & & & & & $300-710$ & $\mathrm{C} 2 \mathrm{D}$ \\
\hline & & \multirow{4}{*}{$\begin{array}{l}\text { Amino C6 } \\
\text { methacrylate }\end{array}$} & \multirow{4}{*}{$\begin{array}{c}\mathrm{NH}_{2} \\
\text { (long spacer) }\end{array}$} & \multirow{2}{*}{$300-600$} & $150-300$ & C6A \\
\hline & & & & & $300-710$ & C6B \\
\hline & & & & \multirow{2}{*}{$1200-1800$} & $150-300$ & $\mathrm{C} 6 \mathrm{C}$ \\
\hline & & & & & $300-710$ & C6D \\
\hline & \multirow{6}{*}{$\begin{array}{l}\text { Adsorption } \\
\text { (C18 and S0 } \\
\text { carriers) }\end{array}$} & \multirow{3}{*}{$\begin{array}{l}\text { Octadecyl } \\
\text { methacrylate }\end{array}$} & \multirow{3}{*}{ Octadecyl } & $350-450$ & $150-300$ & $\mathrm{C} 18 \mathrm{~A}$ \\
\hline & & & & \multirow[b]{2}{*}{$500-700$} & $150-300$ & $\mathrm{C} 18 \mathrm{C}$ \\
\hline & & & & & $300-710$ & $\mathrm{C} 18 \mathrm{D}$ \\
\hline & & \multirow{3}{*}{$\begin{array}{l}\text { Macroporous } \\
\text { styrene }\end{array}$} & \multirow{3}{*}{ None } & \multirow{2}{*}{ 900-110 } & $150-300$ & SOA \\
\hline & & & & & $300-710$ & SOB \\
\hline & & & & $950-1200$ & $300-710$ & SOD \\
\hline- & - & - & - & $\begin{array}{l}\text { Pore Diameter } \\
\quad(k D a)\end{array}$ & $\begin{array}{c}\text { Membrane } \\
\text { Diameter (mm) }\end{array}$ & Acronym \\
\hline \multirow{4}{*}{ Membrane } & \multirow{4}{*}{$\begin{array}{c}\text { Covalent } \\
\text { (CEL and PES } \\
\text { carriers) }\end{array}$} & \multirow{2}{*}{ Cellulose (disc) } & \multirow{2}{*}{$\mathrm{NH}_{2}$} & 10 & 47 & CEL10 \\
\hline & & & & 100 & 47 & CEL100 \\
\hline & & \multirow{2}{*}{$\begin{array}{l}\text { Polyethersulfone } \\
\text { (disc) }\end{array}$} & \multirow{2}{*}{$\mathrm{NH}_{2}$} & 10 & 47 & PES10 \\
\hline & & & & 100 & 47 & PES100 \\
\hline
\end{tabular}

\subsubsection{Yield of LAC Immobilisation}

The amount of LAC immobilised $\left(L A C_{i m m}\right)$ was calculated based on the difference between the loaded concentration of LAC protein on the support $\left(L A C_{\text {load }}\right)$ and the concentration of protein present in eluates obtained after washing out of unbound laccase from the support $\left(L A C_{\text {unbound }}\right)$ and expressed in $\mathrm{mg}$ of protein per $\mathrm{g}$ of wet mass of the support according to Equation (1). The yield of protein immobilisation was expressed in percent (\%), based on Equation (2):

$$
\begin{gathered}
L A C_{\text {imm }}\left(\frac{\mathrm{mg}}{\mathrm{g}}\right)=L A C_{\text {load }}-L A C_{\text {unbound }} \\
\text { Yield }(\%)=\frac{L A C_{\text {imm }}}{L A C_{\text {load }}} \times 100 \%
\end{gathered}
$$

\subsubsection{Activity of Immobilised LAC}

The activity of immobilised LAC was measured in sodium-tartrate buffer $0.1 \mathrm{M} \mathrm{pH} 3$, at $25^{\circ} \mathrm{C}$, using ABTS as a substrate. The activity $\left(A_{\text {imm }}\right)$ was calculated based on formula 3 and expressed in $\mathrm{U}$ per gram of wet mass of the support $(\mathrm{U} / \mathrm{g})$, which is the amount of enzyme able to oxidise $1 \mu \mathrm{mol}$ of ABTS, where $\Delta A_{\min }$ is the absorbance per minute, $V t$ is the total volume of the sample $(2.8 \mathrm{~mL}), \varepsilon_{414}$ is the ABTS molar absorption coefficient (34.450), $t$ is the time of reaction (1 min), and $m$ is the mass of the support used in the reaction $(\mathrm{g})$ :

$$
A_{\text {imm }}=\frac{A_{\min } * V t}{\varepsilon_{414} * t * m}
$$

The optimisation of the LAC immobilisation conditions was started from the screening of the type of support and the immobilisation technique (Table 7). The next step was the optimisation of $\mathrm{pH}(5-8)$ of phosphate buffer used for immobilisation. Those steps of the experiments were performed using $0.5 \mathrm{~g}$ of wet mass of each carrier on which $1 \mathrm{mg}$ of laccase per $1 \mathrm{~g}$ of carrier was loaded. In the last 
step, a concentration-dependent LAC activity test was performed in the range from $0.5 \mathrm{mg}$ to $4 \mathrm{mg}$ of protein per $1 \mathrm{~g}$ of wet mass of the support. The selection was based on the highest measured activity $(\mathrm{U} / \mathrm{g})$ of LAC attached to the carrier.

\subsubsection{Determination of the Bond Type}

Unbound laccase after covalent immobilisation was washed off from the carriers using different buffers to break the unspecific bonds formed between the protein molecule and the carrier. Eluted LAC allowed determination of the type of unspecific bonds, such as adsorption (in phosphate eluates), ionic bonds (in $\mathrm{NaCl}$ eluates), van der Waals forces (in phosphate-buffer eluates), and hydrophobic bonds (in water eluates). TRIS-HCl buffer was used to block of unreacted active groups. The wash-off procedure was as follows (10 $\mathrm{mL}$ of buffer per $\mathrm{g}$ of carrier): $0.1 \mathrm{M}$ phosphate buffer $\mathrm{pH} 7$ (washed four times), $0.5 \mathrm{M} \mathrm{NaCl}$ (washed twice for $15 \mathrm{~min}$ ), phosphate-citrate buffer $\mathrm{pH} 5$ (washed three times for $30 \mathrm{~min}$ ), $0.5 \mathrm{M}$ TRIS-HCl pH 7 (washed three times), distilled water (washed six times for $10 \mathrm{~min}$ ), and again $0.1 \mathrm{M}$ phosphate buffer twice. The percent of unspecific bonds allowed calculating the percent of covalent bonds [46].

\subsection{Stability of LAC}

The selected conditions for long-term storage of immobilised LAC were optimised, i.e., the type (Na-tartaric, McIlvain) and $\mathrm{pH}$ values (3.0-6.0) of the buffer and the concentration of Na-tartaric buffer pH 5 and 6 (1-100 mM). Triple preparations of immobilised LAC weighing $0.5 \mathrm{~g}$ each were stored at $4^{\circ} \mathrm{C}$ and the activity of both immobilised and free LAC was measured every second week. The evaluation of thermostability was performed using immobilised LAC samples $(0.1 \mathrm{~g})$ and corresponding activity of free LAC suspended in a buffer that was optimal for the tested carrier. Samples of immobilised and free LAC were incubated at the temperature from $4{ }^{\circ} \mathrm{C}$ to $80^{\circ} \mathrm{C}$ for $24 \mathrm{~h}$. Changes in LAC activity were expressed as a percentage of initial LAC activity (time 0 ).

\subsection{Transformation of Endocrine Disrupting Chemical}

Bisphenol A (BPA) was first transformed in the concentration range from $0.5 \mathrm{mg} / \mathrm{L}$ to $10 \mathrm{mg} / \mathrm{L}$ using LAC immobilised on four different carriers (C2C, C6C, CEL100, and C18C) with final activity of $5 \mathrm{U} / \mathrm{L}$. The amount of bonded protein differed in the case of each carrier and was $1 \mathrm{mg}$ per $1 \mathrm{~g}$ of carriers C2 and C6, $0.25 \mathrm{mg}$ per $1 \mathrm{~g}$ of carrier CEL100, and $0.5 \mathrm{mg}$ per $1 \mathrm{~g}$ of carrier C18. The reaction was performed in 6-well plates containing a mixture of $0.1 \mathrm{M}$ sodium-tartrate buffer $\mathrm{pH} 5.5$ and the substrate. The reaction mixture was incubated on a rotary shaker $(115 \mathrm{rpm})$ at room temperature. The reaction was conducted in a volume of $10 \mathrm{~mL}$ in 6-well plates for $72 \mathrm{~h}$, and samples were taken for analysis every $24 \mathrm{~h}$. Afterwards, transformation of BPA at the concentration of $10 \mathrm{mg} / \mathrm{L}$ was performed using preparations of laccase with final activity of $12 \mathrm{U} / \mathrm{L}$ in analogical conditions. The amount of immobilised protein was increased to $4 \mathrm{mg} / \mathrm{g}$ of carriers C2 and C6 or $1 \mathrm{mg} / \mathrm{g}$ of carriers CEL100 and C18. In every step, control experiments of substrate absorption were performed using immobilised bovine serum albumin (BSA) at a concentration adequate to the concentration of immobilised laccase of $1 \mathrm{mg} / \mathrm{g}$ or $4 \mathrm{mg} / \mathrm{g}$ incubated with a mixture of the sodium-tartrate buffer and the substrate.

The reusability of immobilised LAC was performed for carriers C2C, C6C and CEL100 in analogical conditions using LAC final activity of $12 \mathrm{U} / \mathrm{L}$. Between each batch the carriers were washed 5-times using $5 \mathrm{~mL}$ of $0.1 \mathrm{M}$ sodium-tartrate buffer $\mathrm{pH} 5$.

\subsection{High Pressure Liquid Chromatogrpahy (HPLC)}

Transformation mixtures containing samples of BPA were analysed using a Zorbax Eclipse-C18 reverse-phase HPLC column (Agilent ${ }^{\circledR}$, Santa Clara, CA, USA) and eluent consisting of $70 \%$ methanol. The sample volume was $5 \mu \mathrm{L}$ and the analysis lasted $3 \mathrm{~min}$. A signal was recorded at $275 \mathrm{~nm}$ and $225 \mathrm{~nm}$. 


\subsection{Ecotoxicity Microtox ${ }^{\circledR}$ Test}

The environmental toxicity test of BPA and the product of its transformation by immobilised laccase was carried out according to the Microtox ${ }^{\circledR}$ biotest methodology, which consists in analysing the decrease in the bioluminescence of Vibrio fisheri bacteria under the influence of the tested compound. The results demonstrated a $50 \%$ decrease in bioluminescence intensity designated $\mathrm{EC}_{50}$, i.e., the concentration of tested substances producing a $50 \%$ effect. The initial concentration of $\mathrm{BPA}$ in this test was $10 \mathrm{mg} / \mathrm{L}$.

\subsection{MTT and LDH Cytotoxicity Tests}

The cytotoxicity tests examined the effect of BPA and the product of its transformation on the metabolic activity and integrity of the cell membrane in human colon epithelial cells of the CCD-841CoTr line. The solution of BPA and the mixture after its transformation used for the tests were diluted 2.5-times in a $2 \%$ solution of foetal bovine serum and a $4 \mathrm{mg} / \mathrm{L}$ final concentration solution was obtained, which corresponds to a concentration of $17 \mathrm{mM}$. Cell viability tests using tetrazolium salt (MTT) and lactate dehydrogenase activity (LDH) methods were performed according to the methodology described in the literature [47].

\section{Conclusions}

The aim of present work was to describe novel porous Purolite ${ }^{\circledR}$ carriers and ultrafiltration membranes, which had never been tested before as supports for laccase immobilisation, and their utility in BPA degradation through biocatalysis. It is important, that commercially available carriers were tested for this process. The main impact on the activity of immobilised LAC was exerted by the structure of the carrier, which should have a well-developed porosity structure with simultaneously small particle size. The immobilised laccase preparations were stable for one month with certain diversity depending on the immobilisation technique. The selected immobilised LAC preparations proved useful for BPA elimination by both enzymatic conversion and by adsorption of the substrate on the carrier surface. It is reasonable to use enzymatic degradation of BPA for reduction of its ecotoxicity and cytotoxicity, mainly damage to the cell membrane. However, more studies are necessary to determine kinetic parameters of immobilised laccase as well as the operational stability of the most efficient carrier.

Author Contributions: Conceptualization, K.W., J.P., A.J.-W.; Methodology, all; Validation, K.W., J.P.; Investigation, K.W., J.K.-P., M.G., R.P.; Resources, all; Data curation, K.W.; Writing-original draft preparation, K.W.; Writing-review and editing, K.W., J.P., A.J.-W.; Visualization, K.W., J.P.; Supervision, K.W., J.P., A.J.-W.; Project administration, K.W., J.P., A.J.-W.; Funding acquisition, K.W. All authors have read and agreed to the published version of the manuscript.

Funding: This work was supported by National Science Centre (Poland), grant number 2015/17/N/NZ9/03647.

Conflicts of Interest: The authors declare no conflict of interest. The funders had no role in the design of the study; in the collection, analyses, or interpretation of data; in the writing of the manuscript, or in the decision to publish the results.

\section{Abbreviations}

LAC laccase

BPA bisphenol A

\section{References}

1. Mateo, C.; Palomo, J.M.; Fernandez-Lorente, G.; Guisan, J.M.; Fernandez-Lafuente, R. Improvement of enzyme activity, stability and selectivity via immobilization techniques. Enzym. Microb. Technol. 2007, 40, 1451-1463. [CrossRef]

2. Peralta-Zamora, P.; Pereira, C.M.; Tiburtius, E.R.; Moraes, S.G.; Rosa, M.A.; Minussi, R.C.; Durán, N. Decolorization of reactive dyes by immobilized laccase. Appl. Catal. B Environ. 2003, 42, 131-144. [CrossRef] 
3. Spinelli, D.; Fatarella, E.; Di Michele, A.; Pogni, R. Immobilization of fungal (Trametes versicolor) laccase onto Amberlite IR-120 H beads: Optimization and characterization. Process Biochem. 2013, 48, 218-223. [CrossRef]

4. Gonçalves, M.C.P.; Kieckbusch, T.G.; Perna, R.F.; Fujimoto, J.T.; Morales, S.A.V.; Romanelli, J.P. Trends on enzyme immobilization researches based on bibliometric analysis. Process Biochem. 2019, 76, 95-110. [CrossRef]

5. Fernández-Fernández, M.; Sanromán, M.Á.; Moldes, D. Recent developments and applications of immobilized laccase. Biotechnol. Adv. 2013, 31, 1808-1825. [CrossRef]

6. Galliker, P.; Hommes, G.; Schlosser, D.; Corvini, P.F.X.; Shahgaldian, P. Laccase-modified silica nanoparticles efficiently catalyze the transformation of phenolic compounds. J. Colloid Interface Sci. 2010, 349, 98-105. [CrossRef]

7. Costa, J.B.; Lima, M.J.; Sampaio, M.J.; Neves, M.C.; Faria, J.L.; Morales-Torres, S.; Tavarez, A.P.M.; Silva, C.G. Enhanced biocatalytic sustainability of laccase by immobilization on functionalized carbon nanotubes/polysulfone membranes. Chem. Eng. J. 2019, 355, 974-985. [CrossRef]

8. Wlizło, K.; Polak, J.; Jarosz-Wilkołazka, A.; Pogni, R.; Petricci, E. Novel textile dye obtained through transformation of 2-amino-3-methoxybenzoic acid by free and immobilised laccase from a Pleurotus ostreatus strain. Enzym. Microb. Technol. 2020, 132, 109398. [CrossRef]

9. Mogharabi, M.; Nassiri-Koopaei, N.; Bozorgi-Koushalshahi, M.; Nafissi-Varcheh, N.; Bagherzadeh, G.; Faramarzi, M.A. Immobilization of laccase in alginate-gelatin mixed gel and decolorization of synthetic dyes. Bioinorg. Chem. Appl. 2012, 2012, 1-6. [CrossRef]

10. Lassouane, F.; Aït-Amar, H.; Amrani, S.; Rodriguez-Couto, S. A promising laccase immobilization approach for Bisphenol A removal from aqueous solutions. Bioresour. Technol. 2019, 271, 360-367. [CrossRef]

11. Mohamad, N.R.; Marzuki, N.H.C.; Buang, N.A.; Huyop, F.; Wahab, R.A. An overview of technologies for immobilization of enzymes and surface analysis techniques for immobilized enzymes. Biotechnol. Biotechnol. Equip. 2015, 29, 205-220. [CrossRef] [PubMed]

12. Nisha, S.; Karthick, S.A.; Gobi, N. A review on methods, application and properties of immobilized enzyme. Chem. Sci. Rev. Lett. 2012, 1, 148-155.

13. de Bezerra, T.M.S.; Bassan, J.C.; de Santos, V.T.O.; Ferraz, A.; Monti, R. Covalent immobilization of laccase in green coconut fiber and use in clarification of apple juice. Process Biochem. 2015, 50, 417-423. [CrossRef]

14. Durán, N.; Rosa, M.A.; D'Annibale, A.; Gianfreda, L. Applications of laccases and tyrosinases (phenoloxidases) immobilized on different supports: A review. Enzym. Microb. Technol. 2002, 31, 907-931. [CrossRef]

15. Asgher, M.; Shahid, M.; Kamal, S.; Iqbal, H.M.N. Recent trends and valorization of immobilization strategies and ligninolytic enzymes by industrial biotechnology. J. Mol. Catal. B Enzym. 2014, 101, 56-66. [CrossRef]

16. Bautista, L.F.; Morales, G.; Sanz, R. Immobilization strategies for laccase from Trametes versicolor on mesostructured silica materials and the application to the degradation of naphthalene. Bioresour. Technol. 2010, 101, 8541-8548. [CrossRef]

17. Hou, J.; Dong, G.; Ye, Y.; Chen, V. Enzymatic degradation of bisphenol-A with immobilized laccase on $\mathrm{TiO}_{2}$ sol-gel coated PVDF membrane. J. Membr. Sci. 2014, 469, 19-30. [CrossRef]

18. Fernández-Lorente, G.; Lopez-Gallego, F.; Bolivar, J.M.; Rocha-Martin, J.; Moreno-Perez, S.; Guisán, J.M. Immobilization of proteins on glyoxyl activated supports: Dramatic stabilization of enzymes by multipoint covalent attachment on pre-existing supports. Curr. Org. Chem. 2015, 19, 13. [CrossRef]

19. Pezzella, C.; Russo, M.E.; Marzocchella, A.; Salatino, P.; Sannia, G. Immobilization of a Pleurotus ostreatus laccase mixture on perlite and its application to dye decolourisation. BioMed. Res. Int. 2014, 2014, 308613. [CrossRef]

20. Tentori, F.; Bavaro, T.; Brenna, E.; Colombo, D.; Monti, D.; Semproli, R.; Ubiali, D. Immobilization of Old Yellow Enzymes via Covalent or Coordination Bonds. Catalysts 2020, 10, 260. [CrossRef]

21. Wang, F.; Guo, C.; Yang, L.R.; Liu, C.Z. Magnetic mesoporous silica nanoparticles: Fabrication and their laccase immobilization performance. Bioresour. Technol. 2010, 101, 8931-8935. [CrossRef] [PubMed]

22. Wang, F.; Guo, C.; Liu, H.Z.; Liu, C.Z. Immobilization of Pycnoporus sanguineus laccase by metal affinity adsorption on magnetic chelator particles. J. Chem. Technol. Biotechnol. 2008, 83, 97-104. [CrossRef]

23. Rahmani, K.; Faramarzi, M.A.; Mahvi, A.H.; Gholami, M.; Esrafili, A.; Forootanfar, H.; Farzadkia, M. Elimination and detoxification of sulfathiazole and sulfamethoxazole assisted by laccase immobilized on porous silica beads. Int. Biodeterior. Biodegrad. 2015, 97, 107-114. [CrossRef] 
24. Lin, J.; Liu, Y.; Chen, S.; Le, X.; Zhou, X.; Zhao, Z.; Ou, Y.; Yang, J. Reversible immobilization of laccase onto metal-ion-chelated magnetic microspheres for bisphenol A removal. Int. J. Biol. Macromol. 2016, 84, 189-199. [CrossRef]

25. Liu, Y.; Zeng, Z.; Zeng, G.; Tang, L.; Pang, Y.; Li, Z.; Liu, C.; Lei, X.; Wu, M.; Ren, P.; et al. Immobilization of laccase on magnetic bimodal mesoporous carbon and the application in the removal of phenolic compounds. Bioresour. Technol. 2012, 115, 21-26. [CrossRef]

26. Xu, R.; Si, Y.; Wu, X.; Li, F.; Zhang, B. Triclosan removal by laccase immobilized on mesoporous nanofibers: Strong adsorption and efficient degradation. Chem. Eng. J. 2014, 255, 63-70. [CrossRef]

27. Sathishkumar, P.; Kamala-Kannan, S.; Cho, M.; Kim, J.S.; Hadibarata, T.; Salim, M.R.; Oh, B.T. Laccase immobilization on cellulose nanofiber: The catalytic efficiency and recyclic application for simulated dye effluent treatment. J. Mol. Catal. B Enzym. 2014, 100, 111-120. [CrossRef]

28. Michałowicz, J. Bisphenol A-Sources, toxicity and biotransformation. Environ. Toxicol. Pharmacol. 2014, 37, 738-758. [CrossRef]

29. Rogala, D.; Kulik-Kupka, K.; Śnieżek, E.; Janicka, A.; Moskalenko, O. Bisfenol A-Niebezpieczny związek ukryty w tworzywach sztucznych. Probl. Hig. Epidemiol. 2016, 97, 213-219.

30. Sifakis, S.; Androutsopoulos, V.P.; Tsatsakis, A.M.; Spandidos, D.A. Human exposure to endocrine disrupting chemicals: Effects on the male and female reproductive systems. Environ. Toxicol. Pharmacol. 2017, 51, 56-70. [CrossRef]

31. Castro, B.; Sanchez, P.; Torres, J.M.; Preda, O.; del Moral, R.G.; Ortega, E. Bisphenol A exposure during adulthood alters expression of aromatase and $5 \alpha$-reductase isozymes in rat prostate. PLOS ONE 2013, 8, e55905. [CrossRef] [PubMed]

32. Konieczna, A.; Rutkowska, A.; Rachon, D. Health risk of exposure to bisfenol A (BPA). Rocz. Państ. Zakt. Hig. 2015, 66, 5-11.

33. Nair, R.R.; Demarche, P.; Agathos, S.N. Formulation and characterization of an immobilized laccase biocatalyst and its application to eliminate organic micropollutants in wastewater. New Biotechnol. 2013, 30, 814-823. [CrossRef] [PubMed]

34. Zdarta, J.; Antecka, K.; Frankowski, R.; Zgoła-Grześkowiak, A.; Ehrlich, H.; Jesionowski, T. The effect of operational parameters on the biodegradation of bisphenols by Trametes versicolor laccase immobilized on Hippospongia communis spongin scaffolds. Sci. Total Environ. 2018, 615, 784-795. [CrossRef] [PubMed]

35. Sadeghzadeh, S.; Nejad, Z.G.; Ghasemi, S.; Khafaji, M.; Borghei, S.M. Removal of bisphenol A in aqueous solution using magnetic cross-linked laccase aggregates from Trametes hirsuta. Bioresour. Technol. 2020, 306, 123169. [CrossRef]

36. Dudziak, M. Wpływ warunków środowiska wodnego na rozkład bisfenolu A. Proc. ECOpolen 2017, 11, 131-139.

37. Varga, B.; Somogyi, V.; Meiczinger, M.; Kováts, N.; Domokos, E. Enzymatic treatment and subsequent toxicity of organic micropollutants using oxidoreductases-A review. J. Clean. Prod. 2019, 221, 306-322. [CrossRef]

38. Spina, F.; Cordero, C.; Schilirò, T.; Sgorbini, B.; Pignata, C.; Gilli, G.; Bichi, C.; Varese, G.C. Removal of micropollutants by fungal laccases in model solution and municipal wastewater: Evaluation of estrogenic activity and ecotoxicity. J. Clean. Prod. 2015, 100, 185-194. [CrossRef]

39. de Freitas, E.N.; Bubna, G.A.; Brugnari, T.; Kato, C.G.; Nolli, M.; Rauen, T.G.; Moreira, R.F.P.M.; Peralta, R.A.; Bracht, A.; de Souza, C.G.M.; et al. Removal of bisphenol A by laccases from Pleurotus ostreatus and Pleurotus pulmonarius and evaluation of ecotoxicity of degradation products. Chem. Eng. J. 2017, 330, 1361-1369. [CrossRef]

40. Wlizło, K.; Polak, J.; Jarosz-Wilkołazka, A. Związki biologicznie aktywne i metody ich usuwania na drodze biokatalizy. Postęp. Biochem. 2017, 63, 304-314.

41. Lan, H.C.; Wu, K.Y.; Lin, I.W.; Yang, Z.J.; Chang, A.A.; Hu, M.C. Bisphenol A disrupts steroidogenesis and induces a sex hormone imbalance through c-Jun phosphorylation in Leydig cells. Chemosphere 2017, 185, 237-246. [CrossRef] [PubMed]

42. Song, H.; Zhang, T.; Yang, P.; Li, M.; Yang, Y.; Wang, Y.; Du, J.; Pan, K.; Zhang, K. Low doses of bisphenol A stimulate the proliferation of breast cancer cells via ERK1/2/ERR $\gamma$ signals. Toxicol. In Vitro 2015, 302, 521-528. [CrossRef] [PubMed]

43. Lindeberg, G.; Holm, G. Occurrence of tyrosinase and laccase in fruit bodies and mycelia of some Hymenomycetes. Physiol. Plant. 1952, 5, 100-114. [CrossRef] 
44. Bryjak, J.; Kruczkiewicz, P.; Rekuć, A.; Pęczyńska-Czoch, W. Laccase immobilization on copolymer of butyl acrylate and ethylene glycol dimethacrylate. Biochem. Eng. J. 2007, 35, 325-332. [CrossRef]

45. Rekuć, A.; Kruczkiewicz, P.; Jastrzembska, B.; Liesiene, J.; Pęczyńska-Czoch, W.; Bryjak, J. Laccase immobilization on the tailored cellulose-based Granocel carriers. Int. J. Biol. Macromol. 2008, 42, 208-215. [CrossRef]

46. Ginalska, G.; Kowalczuk, D.; Osińska, M. A chemical method of gentamicin bonding to gelatin-sealed prosthetic vascular grafts. Int. J. Pharm. 2005, 288, 131-140. [CrossRef]

47. Polak, J.; Jarosz-Wilkolazka, A.; Szuster-Ciesielska, A.; Wlizlo, K.; Kopycinska, M.; Sojka-Ledakowicz, J.; Lichawska-Olczyk, J. Toxicity and dyeing properties of dyes obtained through laccase-mediated synthesis. J. Clean. Prod. 2016, 112, 4265-4272. [CrossRef]

(C) 2020 by the authors. Licensee MDPI, Basel, Switzerland. This article is an open access article distributed under the terms and conditions of the Creative Commons Attribution (CC BY) license (http://creativecommons.org/licenses/by/4.0/). 